This is a self-archived version of an original article. This version may differ from the original in pagination and typographic details.

Author(s): Ambat, Indu; Srivastava, Varsha; Haapaniemi, Esa; Sillanpää, Mika

Title: Application of Potassium Ion Impregnated Titanium Dioxide as Nanocatalyst for Transesterification of Linseed Oil

Year: 2018

Version: Accepted version (Final draft)

Copyright: (c) 2018 American Chemical Society.

Rights: In Copyright

Rights url: http://rightsstatements.org/page/InC/1.0/?language=en

Please cite the original version:

Ambat, I., Srivastava, V., Haapaniemi, E., \& Sillanpää, M. (2018). Application of Potassium Ion Impregnated Titanium Dioxide as Nanocatalyst for Transesterification of Linseed Oil. Energy and Fuels, 32(11), 11645-11655. https://doi.org/10.1021/acs.energyfuels.8b03310 
Subscriber access provided by JYVASKYLAN UNIV

\title{
Biofuels and Biomass
}

\section{Application potassium ion impregnated titanium dioxide as nanocatalyst for transesterification of linseed oil.}

\author{
Indu Ambat, Varsha Srivastava, Esa Haapaniemi, and Mika Sillanpää
}

Energy Fuels, Just Accepted Manuscript • DOI: 10.1021/acs.energyfuels.8b03310 • Publication Date (Web): 27 Oct 2018

Downloaded from http://pubs.acs.org on October 29, 2018

\section{Just Accepted}

"Just Accepted" manuscripts have been peer-reviewed and accepted for publication. They are posted online prior to technical editing, formatting for publication and author proofing. The American Chemical Society provides "Just Accepted" as a service to the research community to expedite the dissemination of scientific material as soon as possible after acceptance. "Just Accepted" manuscripts appear in full in PDF format accompanied by an HTML abstract. "Just Accepted" manuscripts have been fully peer reviewed, but should not be considered the official version of record. They are citable by the Digital Object Identifier (DOI®). "Just Accepted" is an optional service offered to authors. Therefore, the "Just Accepted" Web site may not include all articles that will be published in the journal. After a manuscript is technically edited and formatted, it will be removed from the "Just Accepted" Web site and published as an ASAP article. Note that technical editing may introduce minor changes to the manuscript text and/or graphics which could affect content, and all legal disclaimers and ethical guidelines that apply to the journal pertain. ACS cannot be held responsible for errors or consequences arising from the use of information contained in these "Just Accepted" manuscripts. 


\section{Application potassium ion impregnated titanium dioxide as nanocatalyst for}

\section{2 transesterification of linseed oil}

3

4 Indu Ambat ${ }^{a *}$, Varsha Srivastava ${ }^{a}$, Esa Haapaniemi ${ }^{b}$, Mika Sillanpää ${ }^{a}$

5 a Department of Green Chemistry, School of Engineering Science, Lappeenranta University

6 of Technology, Sammonkatu 12, FI-50130 Mikkeli, Finland

7 b Department of Organic Chemistry, University of Jyväskylä, Finland

8 *Corresponding Author (email: indu.ambat@outlook.com)

9

Abstract

11

12 The current work comprises the investigation of biodiesel production from linseed oil 13 using $\mathrm{TiO}_{2}$ and potassium L-tartrate monobasic $\left(\mathrm{C}_{4} \mathrm{H}_{5} \mathrm{KO}_{6}\right)$ modified $\mathrm{TiO}_{2}$ nanocatalyst. The 14 different molar ratio of $\mathrm{C}_{4} \mathrm{H}_{5} \mathrm{KO}_{6}$ was selected for $\mathrm{TiO}_{2}$ modification. The nanocatalyst $\mathrm{TiO}_{2}-$ $150.5 \mathrm{C}_{4} \mathrm{H}_{5} \mathrm{KO}_{6}(1: 0.5$ molar ratio $)$ showed the best conversion rate for biodiesel. Nanocatalyst 16 was characterized by FTIR, XRD, TEM, BET, XPS and Hammett indicators benzene 17 carboxylic acid titration method for basicity measurement. The characterization of biodiesel 18 was performed with GC-MS, ${ }^{1} \mathrm{H}$ and ${ }^{13} \mathrm{C}$ NMR. Furthermore, the optimum reaction 19 parameters for transesterification reaction was analyzed and yield was determined by GC-

$20 \mathrm{MS}$ and ${ }^{1} \mathrm{H}$ NMR. The maximum yield of $98.5 \%$ was obtained at $6 \mathrm{wt} \%$ catalyst amount, 
21 1:6 methanol to oil ratio at $60{ }^{\circ} \mathrm{C}$ for 3 hours. The properties of biodiesel obtained from

22 linseed oil were determined using EN 14214/ ASTM D6751 method. The reusability of 23 catalyst was tested up to five cycles and it showed promising results.

24

25 Key words: Biodiesel, linseed oil, transesterification, $\mathrm{TiO}_{2}-\mathrm{C}_{4} \mathrm{H}_{5} \mathrm{KO}_{6}$ nanocatalyst

26

27 1. Introduction

28

29 The energy crisis is one of the major issue confronted by the whole world due to the 30 dependency on conventional energy reserves ${ }^{1,2}$. In recent days, with an increase in population 31 results in the expeditious utilization of fossil fuels which leads to two major issues, direct 32 environmental pollution and global warming ${ }^{2-4}$. Biodiesel is fatty acid methyl esters (FAME), 33 has been suggested as suitable alternative fuel which is produced by the transesterification of 34 fats/ oils using alcohol mainly methanol or ethanol with a suitable catalyst ${ }^{5-8}$. FAME can act 35 as a renewable source of energy due to its features such as biodegradability and eco-friendly 36 nature 9

37 Generally, vegetable oils, algal oils and animal fat/oils are used as feedstock for biodiesel 38 production ${ }^{10-12}$. The feedstock used for the biodiesel production is preferred to be less 39 expensive as well as does not compete with food production ${ }^{13,14}$. Hence linseed oil was used 40 as feedstock for biodiesel production. Furthermore, the oil content of linseed oil is almost 
41 similar to edible oil such as rapeseed oil and higher than that of soybean and sunflower oil.

42 Moreover, the content of linolenic acid $\left(\mathrm{C}_{18: 3}\right)$ was higher compared to other oils ${ }^{13}$. Kumar et 43 al., ${ }^{15}$ reported 88-96 \% conversion efficiency of linseed oil with alkali transesterification.

44 Gargari and Sadrameli ${ }^{16}$ observed FAMEs yield up to $98.08 \%$ in presence of di-ethyl ether

45 as a co-solvent and calcium oxide as a heterogeneous based catalyst in a fixed bed reactor.

46 The transesterification reaction is commonly conducted using homogeneous catalyst, 47 heterogeneous catalyst, biocatalyst ${ }^{8,9,13,17}$. Currently, heterogeneous nanocatalysts attained 48 greater attraction in the field of biodiesel production due to its features such as increased 49 stability, activity, and selectivity $5,17,18$. Based on previous research reports recommends that 50 potassium doped metal oxides provides promising results in biodiesel production, out of 51 those studies potassium doped on titanium dioxide $\left(\mathrm{TiO}_{2}\right)$ using potassium bitartrate as 52 precursor resulted in good biodiesel yield with both edible and non-edible oils $3,8,19-22$. 53 Additionally, $\mathrm{TiO}_{2}$ alone serves as a catalyst for transesterification and also acts as good 54 support in heterogeneous catalysis due to its high chemical stability, thermal constancy and 55 commercial availability 7,23 . Therefore potassium impregnated on titania using potassium 56 bitartrate as precursor used for biodiesel production from linseed oil.

57 In the present study is targeted on the production of biodiesel from linseed oil using 58 heterogeneous nanocatalyst. The purpose of our work is to investigate the effect of 59 heterogeneous nanocatalysis on linseed oil, which has not been explored yet. Hence 60 potassium impregnated $\mathrm{TiO}_{2}$ as a nanocatalyst was synthesized. The loading effect of $61 \mathrm{C}_{4} \mathrm{H}_{5} \mathrm{KO}_{6}$ on catalytic activity was also investigated. The $\mathrm{TiO}_{2}-0.5 \mathrm{C}_{4} \mathrm{H}_{5} \mathrm{KO}_{6}$ nanocatalyst 62 showed the significant conversion of linseed oil to biodiesel. The characterization of 
63 synthesized nanocatalyst was done using Fourier transform infrared spectroscopy (FTIR),

64 Scanning electron microscopy (SEM), X-ray diffraction (XRD), X-ray photoelectron 65 spectroscopy (XPS), Transmission electron microscopy (TEM), Atomic-force microscopy 66 (AFM) and Brunauer-Emmett-Teller (BET). Further, the nanocatalyst has been used for

67 transesterification reaction, where the production conditions such as temperature molar ratio 68 of oil and methanol, catalyst amount and time were optimized. The biodiesel was analyzed 69 by gas chromatography with a mass spectrometry (GC-MS), ${ }^{1} \mathrm{H}$ and ${ }^{13} \mathrm{C}$ nuclear magnetic 70 resonance $(\mathrm{NMR})$.

72 2. Materials and methods

73

$74 \quad 2.1$ Material

75

76 Linseed oil (acid value $=0.606 \mathrm{mg} \mathrm{KOH} / \mathrm{g}$, average molecular weight=887.9354), titanium 77 oxide nanopowder $\left(\mathrm{TiO}_{2}\right)$, Potassium bitartrate $\left(\mathrm{C}_{4} \mathrm{H}_{5} \mathrm{KO}_{6}\right)$, methanol were purchased from 78 Sigma-Aldrich. All the chemicals used were of analytical grade

79

$80 \quad 2.2$ Synthesis and screening of catalyst

81 
82 The titanium dioxide modified by $\mathrm{C}_{4} \mathrm{H}_{5} \mathrm{KO}_{6}$ was synthesized by the impregnation method.

83 In this method, catalysts were prepared by mixing $\mathrm{TiO}_{2} / \mathrm{C}_{4} \mathrm{H}_{5} \mathrm{KO}_{6}$ in different molar ratios of

$841: 0.25,1: 0.5,1: 0.75$ and $1: 1$. The solutions were stirred continuously for $5 \mathrm{~h}$ and subsequently

85 dried at $90^{\circ} \mathrm{C}$. Finally, dried samples were calcined at $500^{\circ} \mathrm{C}$ in the muffle furnace

86 (Naberthermb180). The $\mathrm{TiO}_{2}$, a series of synthesized catalysts by mixing of $\mathrm{TiO}_{2} / \mathrm{C}_{4} \mathrm{H}_{5} \mathrm{KO}_{6}$

87 in various molar ratios were screened for fatty acid methyl ester (FAME) production.

88 Furthermore, synthesis of series of the catalyst by doping of various concentration of

89 potassium ion to titania helps to investigate the capability of different catalyst in the

90 transesterification of linseed oil as well as it provides the effect of $\mathrm{C}_{4} \mathrm{H}_{5} \mathrm{KO}_{6}$ loading on the

91 catalytic activity of titanium oxide.

92

$93 \quad 2.3$ Characterization of catalyst

94

95 The FTIR of catalysts were recorded using Vertex 70 Bruker in the range of 400- 4000 $96 \mathrm{~cm}^{-1}$. TEM images of the samples were obtained using HT7700 (Hitachi). The nanocatalyst 97 was dispersed in ethanol with help of sonication, in order to obtain dispersed particles on the 98 suspension. Later a drop of suspension was added to the carbon-coated copper grid. SEM 99 images of catalysts were recorded by spreading sample on colloidal graphite with $5 \mathrm{kV}$ 100 accelerating voltage (SEM, Hitachi SU3500). XRD patterns were obtained with PANalytical 101 - Empyrean X-ray diffractometer over a $2 \theta$ range of $10-120^{\circ}$ with an X-ray source Co-K $\alpha$ of $1020.178 \mathrm{~nm}$ at $40 \mathrm{~mA}$ and $40 \mathrm{kV}$. The surface area of catalyst was determined using BET (BET, 
103 Micromeritics Tristar II plus). The catalyst samples were degassed at $80^{\circ} \mathrm{C}$ for overnight to 104 remove the moisture from the samples.

105 AFM (Park Systems NX10) images of nanocatalyst were also collected for better 106 illustration of nanocatalyst. The surface composition and the binding energies of elements 107 in nanocatalyst were examined by ESCALAB 250 model XPS with an Al-K X-ray source of $108 \quad 1486.6 \mathrm{eV}$. The basicity test of catalyst was performed with help of Hammett indicator 109 benzene carboxylic acid titration method. Hammett indicator-benzene carboxylic acid (0.02 110 mol L-1 anhydrous methanol solution) titration method was performed to determine basic 111 strength of synthesized catalyst using Hammett indicators such as neutral red ( H_6.8), 112 bromothymol blue (H_7.2), phenolphthalein (H_9.8), 2, 4 - dinitroaniline (H_15) 24,25 .

$114 \quad 2.4$ Biodiesel production

Linseed oil was used as feedstock for biodiesel production. The screening of different 117 catalyst was done by performing the reaction by mixing oil to methanol in 1:6 molar ratio 118 and with $6 \mathrm{wt} \%$ of each catalyst. All the reactions were carried out in a $250 \mathrm{ml}$ three neck 119 round bottom flask with mechanical stirrer and reflux condenser at $60^{\circ} \mathrm{C}$ for $3 \mathrm{~h}$. After the 120 reaction, the samples were centrifuged, resulted in three separate phases such as catalyst at 121 the bottom, methyl ester at top and glycerol at the middle. The catalyst was isolated, excess 122 methanol was removed by the evaporator and the obtained biodiesel was analyzed by GC123 MS (Agilent-GC6890N, MS 5975) with an Agilent DB-wax FAME analysis GC column 
124 dimensions $30 \mathrm{~m}, 0.25 \mathrm{~mm}, 0.25 \mu \mathrm{m}$. The inlet temperature was $250^{\circ} \mathrm{C}$ and oven temperature 125 was programmed at $50^{\circ} \mathrm{C}$ for $1 \mathrm{~min}$ and it raises at the rate of $25^{\circ} \mathrm{C} / \mathrm{min}$ to $200^{\circ} \mathrm{C}$ and $3^{\circ} \mathrm{C}$ $126 / \mathrm{min}$ to $230^{\circ} \mathrm{C}$ and then it was held for $23 \mathrm{~min}$. The concentration and presence of ester 127 carbonyl groups of fatty acid methyl esters were determined by ${ }^{1} \mathrm{H} N \mathrm{NM}$ and ${ }^{13} \mathrm{C}$ NMR at $128400 \mathrm{MHz}$ with $\mathrm{CDCl}_{3}$ as solvent, respectively. The percentage of linseed oil conversion to 129 fatty acid methyl esters (C \%) was determined by the equation given below ${ }^{13}$.

$$
C(\%)=\frac{2 \times \text { Intergration value of protons of methyl ester }}{3 \times \text { Intergraton value of methyl protons }} \times 100(\text { Eq. } 2)
$$

131

132 3. Result and discussion

The selection of nanocatalyst for the biodiesel production from linseed oil was obtained

137 by screening of the catalytic activity of different catalyst such as $\mathrm{TiO}_{2}, \mathrm{TiO}_{2} / \mathrm{C}_{4} \mathrm{H}_{5} \mathrm{KO}_{6}$ $138(1: 0.25,1: 0.5,1: 0.75$ and $1: 1$ molar ratios $)$ at $60^{\circ} \mathrm{C}$ with $6 \mathrm{wt} \%$ of each catalyst and $1: 6$ oil 139 to methanol molar ratio for $3 \mathrm{~h}$. The catalyst composition, surface area, total basicity of 140 synthesized catalyst and catalytic performance of each catalyst was indicated in Table1. Basic 141 nature and total basicity of synthesized catalyst was determined by Hammett indicator142 benzene carboxylic acid titration method ${ }^{8,24-26}$. The $\mathrm{TiO}_{2}$ showed no reaction and it is 143 probably due to lower basic strength. Later the basicity of catalyst rises with the loading 
144 amount of $\mathrm{C}_{4} \mathrm{H}_{5} \mathrm{KO}_{6}$ that increases the activity of the catalyst. Further increase in the $145 \mathrm{C}_{4} \mathrm{H}_{5} \mathrm{KO}_{6}$ amount after optimum value, reduces the catalytic activity possibly due to a 146 decrease in both surface area and basicity. The $\mathrm{TiO}_{2} / \mathrm{C}_{4} \mathrm{H}_{5} \mathrm{KO}_{6}$ with 1:0.5 ratio showing the 147 significant conversion of biodiesel from linseed oil due to the optimum loading of $\mathrm{C}_{4} \mathrm{H}_{5} \mathrm{KO}_{6}$. 148 Therefore, $\mathrm{TiO}_{2}-0.5 \mathrm{C}_{4} \mathrm{H}_{5} \mathrm{KO}_{6}$ was selected for the optimization of reaction parameters for 149 higher production of biodiesel.

150

151 Table 1.

152 The efficiency of various catalyst for transesterification of linseed oil

\begin{tabular}{clcccc}
\hline No. & Catalyst & Molar ratio & Total basicity & BET surface & FAME \\
& & & $\left(\mathrm{mmol} \mathrm{g}^{-1}\right)$ & area $\left(\mathrm{m}^{2} \mathrm{~g}^{-1}\right)$ & conversion $(\%)$ \\
\hline 1 & $\mathrm{TiO}_{2}$ & - & 0.1 & 37.58 & No reaction \\
\hline 2 & $\mathrm{TiO}_{2} / \mathrm{C}_{4} \mathrm{H}_{5} \mathrm{KO}_{6}$ & $1: 0.25$ & 0.3 & 25.43 & 45 \\
\hline 3 & $\mathrm{TiO}_{2} / \mathrm{C}_{4} \mathrm{H}_{5} \mathrm{KO}_{6}$ & $1: 0.5$ & 1.80 & 16.25 & 98.54 \\
\hline 4 & $\mathrm{TiO}_{2} / \mathrm{C}_{4} \mathrm{H}_{5} \mathrm{KO}_{6}$ & $1: 0.75$ & 1.56 & 10.65 & 80.10 \\
\hline 5 & $\mathrm{TiO}_{2} / \mathrm{C}_{4} \mathrm{H}_{5} \mathrm{KO}_{6}$ & $1: 1$ & 0.89 & 7.37 & 50.88
\end{tabular}

153

$154 \quad$ 3.2. Characterization of catalyst

155

156 The FTIR peaks of unmodified $\mathrm{TiO}_{2}$ and $\mathrm{TiO}_{2}-0.5 \mathrm{C}_{4} \mathrm{H}_{5} \mathrm{KO}_{6}$ were shown in Figure 1. In the

157 FTIR spectrum of $\mathrm{TiO}_{2}-0.5 \mathrm{C}_{4} \mathrm{H}_{5} \mathrm{KO}_{6}$ shows new peaks at $895.82 \mathrm{~cm}^{-1}, 1368.324 \mathrm{~cm}^{-1}$ and 
$1581458.00 \mathrm{~cm}^{-1}$. New peaks could be due to the integration of potassium ions into the $\mathrm{TiO}_{2}$

159 structure. However, it also indicates broadband in range of $2900 \mathrm{~cm}^{-1}$ to $3300 \mathrm{~cm}^{-1}$ due to 160 stretching vibrations of Ti-O-K bond ${ }^{3,19}$.

161

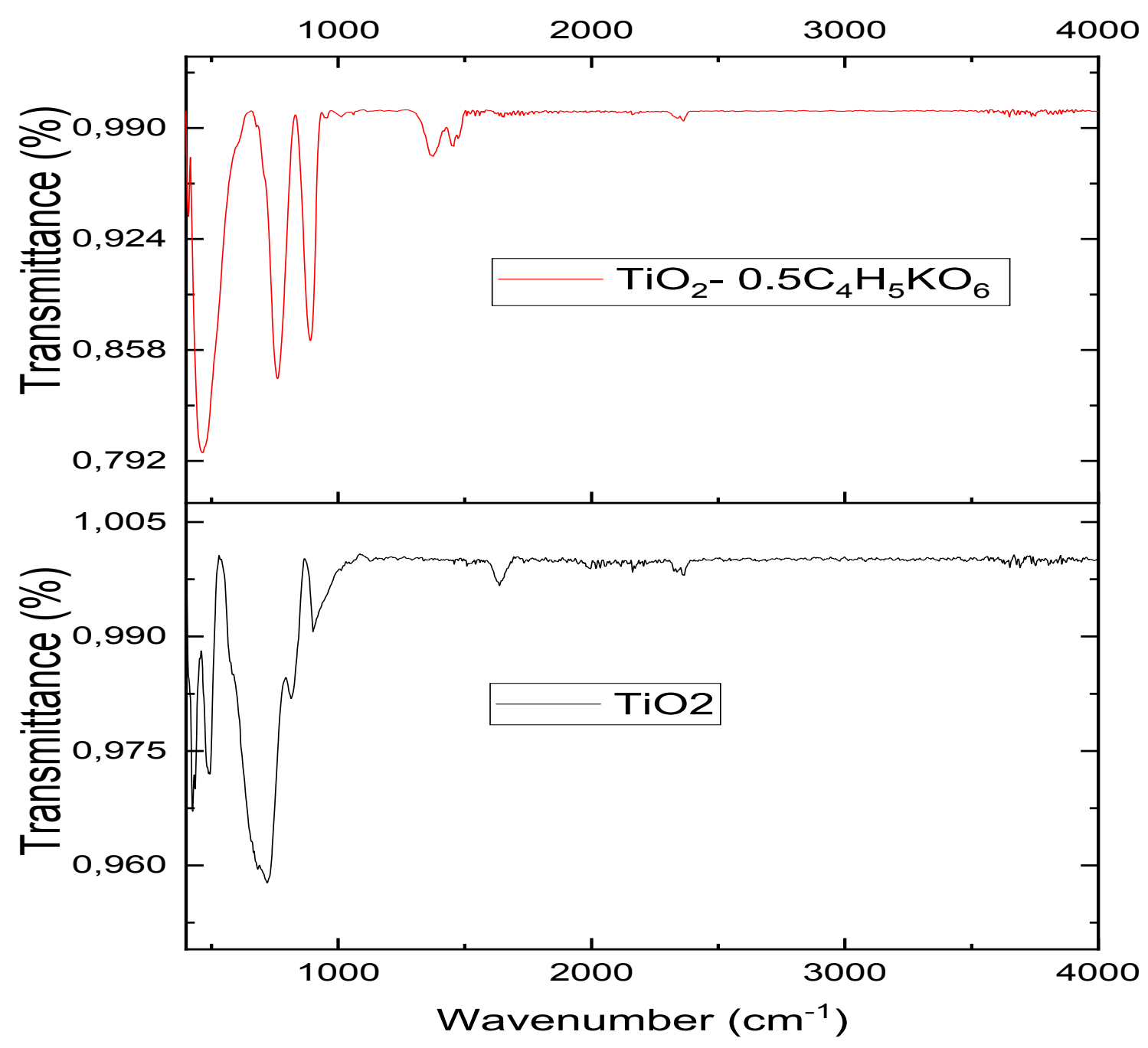

162

163 Figure 1. FTIR spectra of $\mathrm{TiO}_{2}$ (unmodified) and $\mathrm{TiO}_{2}-\mathrm{C}_{4} \mathrm{H}_{5} \mathrm{KO}_{6}$ (1:0.5molar ratio)

164 
165 Figure 2 shows the XRD pattern of both unmodified $\mathrm{TiO}_{2}$ and $\mathrm{TiO}_{2}-0.5 \mathrm{C}_{4} \mathrm{H}_{5} \mathrm{KO}_{6}$. X-ray 166 diffraction (XRD) analysis of unmodified $\mathrm{TiO}_{2}$ depicts a good match to standard reference 167 code ICSD: 154607, ICDD: 98-015-4607. XRD pattern of Potassium Titanium Oxide 168 obtained as result of modification of $\mathrm{TiO}_{2}$ with 0.5 molar $\mathrm{C}_{4} \mathrm{H}_{5} \mathrm{KO}_{6}$ provides a consistent 169 harmony to reference standard code ICSD:73465, ICDD:98-007-3465. The crystallographic 170 parameters of synthesized catalysts are shown in Table 2.

171 Table 2.

172 The crystallographic parameters of unmodified $\mathrm{TiO}_{2}$ and $\mathrm{TiO}_{2}-0.5 \mathrm{C}_{4} \mathrm{H}_{5} \mathrm{KO}_{6}$.

173

\begin{tabular}{llllllll}
\hline Catalyst & Crystal & a & b & c & $\boldsymbol{\alpha}$ & $\boldsymbol{\beta}$ & $\boldsymbol{\gamma}$ \\
& structure & & & & & & \\
& & & & & & & \\
& & $(\mathrm{nm})$ & $(\mathrm{nm})$ & $(\mathrm{nm})$ & & & \\
& & & & & & & \\
\hline $\mathrm{TiO}_{2}$ & Tetragonal & 0.379 & 0.379 & 0.941 & 90 & 90 & 90 \\
& & & & & & & \\
\hline $\mathrm{TiO}_{2}-0.5 \mathrm{C}_{4} \mathrm{H}_{5} \mathrm{KO}_{6}$ & Tetragonal & 1.02 & 1.02 & 0.296 & 90 & 90 & 90 \\
& & & & & & & \\
\hline
\end{tabular}




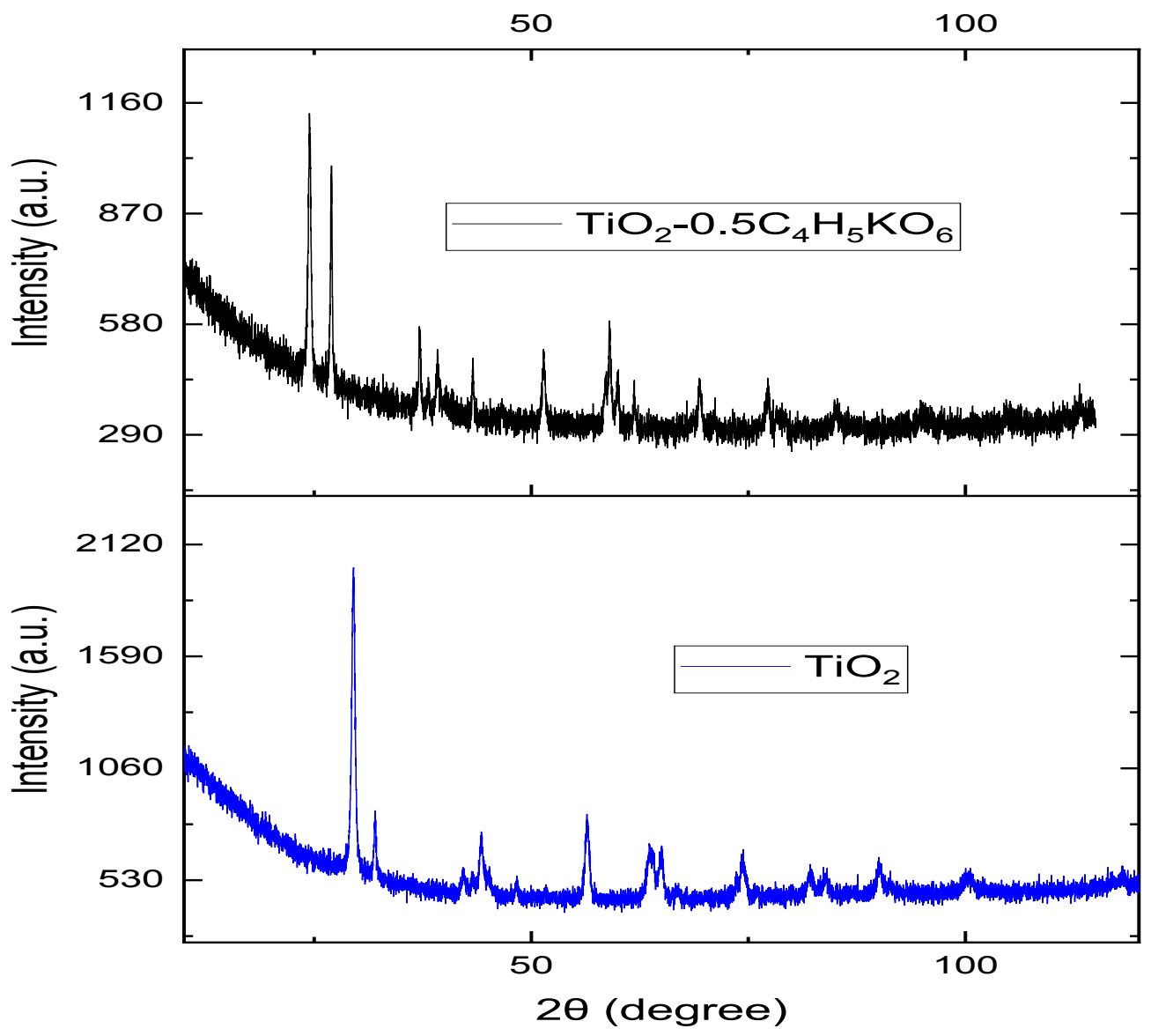

175 Figure 2. XRD pattern of $\mathrm{TiO}_{2}$ (unmodified) and $\mathrm{TiO}_{2}-\mathrm{C}_{4} \mathrm{H}_{5} \mathrm{KO}_{6}(1: 0.5$ molar ratio)

177 images of $\mathrm{TiO}_{2}$ (unmodified) and $\mathrm{TiO}_{2}-\mathrm{C}_{4} \mathrm{H}_{5} \mathrm{KO}_{6}(1: 0.5$ molar ratio) with $5 \mathrm{kV}$ magnification

178 respectively. By comparing two images, it was observed that there was a significant 179 difference in the structure of $\mathrm{TiO}_{2}-\mathrm{C}_{4} \mathrm{H}_{5} \mathrm{KO}_{6}(1: 0.5$ molar ratio) due to the doping of 180 potassium. The unmodified $\mathrm{TiO}_{2}$ catalyst looks fluffier and comparatively uniform particles 181 with some aggregates. It is very clear from SEM image of $\mathrm{TiO}_{2}-0.5 \mathrm{C}_{4} \mathrm{H}_{5} \mathrm{KO}_{6}$ that flat 182 surface of different shapes was dispersed in the catalytic material indicates a different 
183 morphology of particles due to impregnation of potassium particles on the surface of $\mathrm{TiO}_{2}$

184 (Figure 3b).

185

186

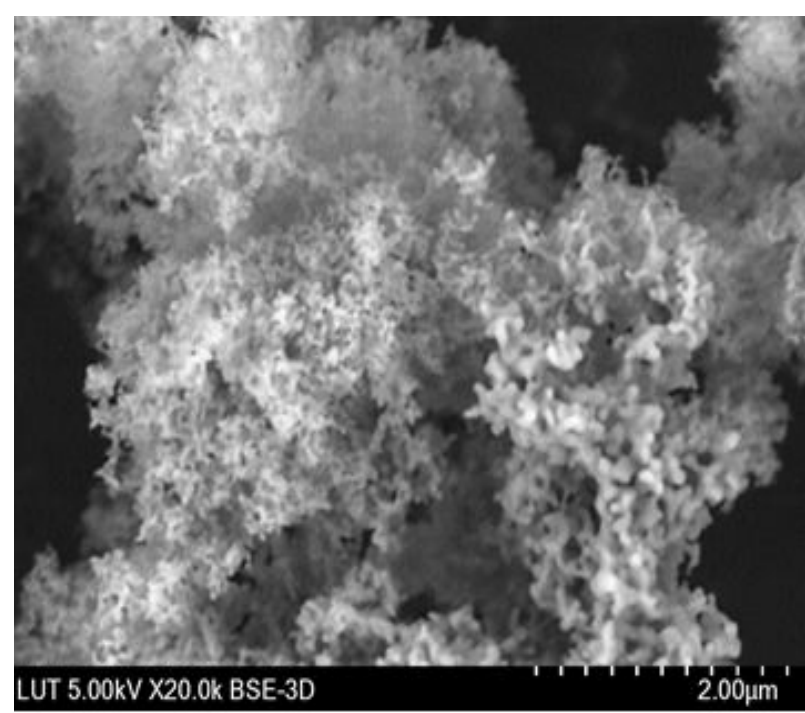

(a)

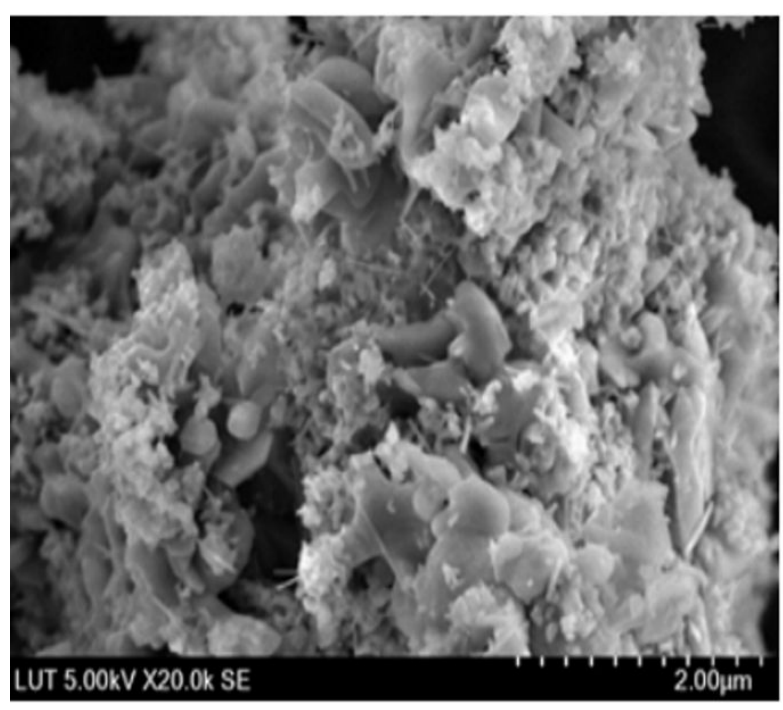

(b)

187

188 Figure 3. SEM images of (a) unmodified $-\mathrm{TiO}_{2}$ (b) $\mathrm{TiO}_{2}-\mathrm{C}_{4} \mathrm{H}_{5} \mathrm{KO}_{6}$ (1:0.5molar ratio) 


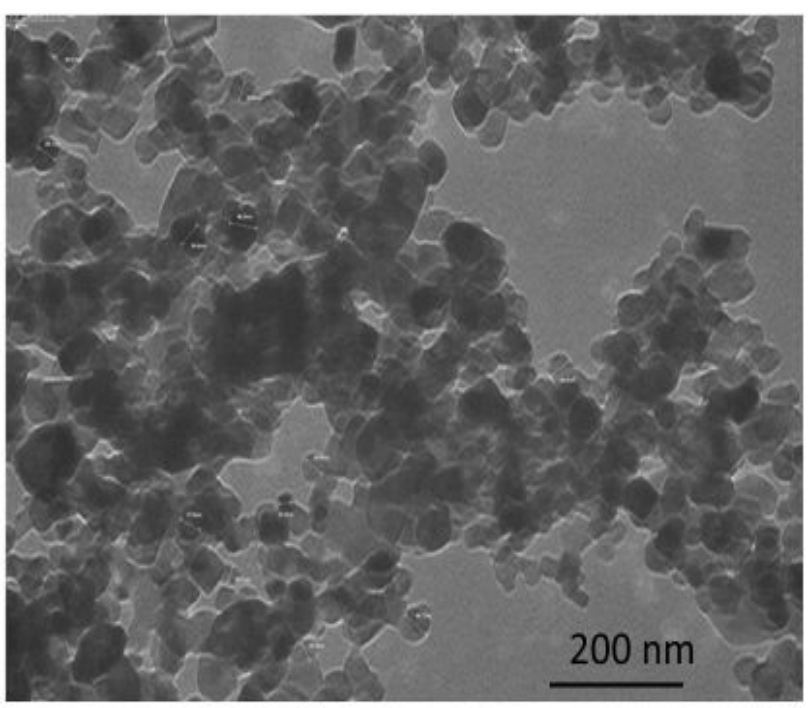

(a)

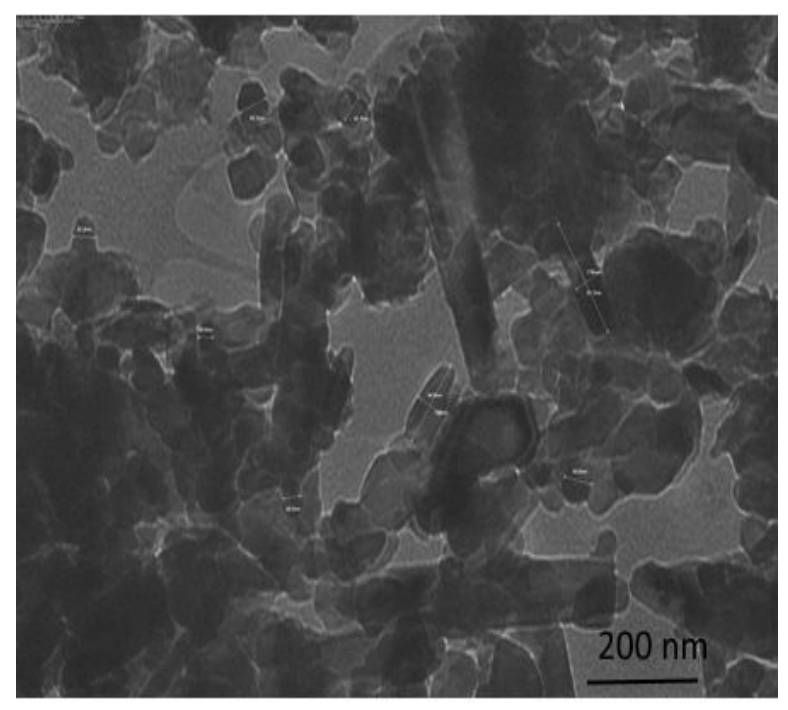

(b)

189

190

Figure 4. TEM image of (a) unmodified $-\mathrm{TiO}_{2}$ and (b) $\mathrm{TiO}_{2}-\mathrm{C}_{4} \mathrm{H}_{5} \mathrm{KO}_{6}$ (1:0.5molar ratio)

191

The TEM image of $\mathrm{TiO}_{2}$ (unmodified) and $\mathrm{TiO}_{2}-\mathrm{C}_{4} \mathrm{H}_{5} \mathrm{KO}_{6}$ (1:0.5molar ratio) were 193 depicted in Figure 4a and 4b respectively. The $\mathrm{TiO}_{2}$ (unmodified) catalyst has a particle size 194 of 23- 46.7nm whereas $\mathrm{TiO}_{2}-\mathrm{C}_{4} \mathrm{H}_{5} \mathrm{KO}_{6}(1: 0.5$ molar ratio) modified catalyst has a particle size 195 of 26-179nm. The size of the particle in the catalyst was confirmed with help of TEM images.

196 Moreover, TEM image of $\mathrm{TiO}_{2}$ (unmodified) also represents a well distributed large quantity 197 of uniform particle with agglomerates, while TEM studies of $\mathrm{TiO}_{2}-0.5 \mathrm{C}_{4} \mathrm{H}_{5} \mathrm{KO}_{6}$ show long 198 flat structure in addition to uniform particles with aggregates. SEM results also match with 199 TEM images.

200 The AFM image of $\mathrm{TiO}_{2}$ and $\mathrm{TiO}_{2}-\mathrm{C}_{4} \mathrm{H}_{5} \mathrm{KO}_{6}$ were portrayed Figure $5(\mathrm{a}, \mathrm{b})$ with scan rate 201 and amplitude of $0.26 \mathrm{~Hz}$ and $15.04 \mathrm{E} 3 \mathrm{~nm}$ respectively. AFM image also agrees with the 
202 integration of potassium ions into titanium dioxide nanocatalyst. All the dimensions were

203 shown in nanoscale. Particle dimensions measured with AFM images well agreed with TEM

204 analysis and supported potassium loading. All the catalyst characterization confirms the

205 impregnation of potassium ion to titania.

206

207
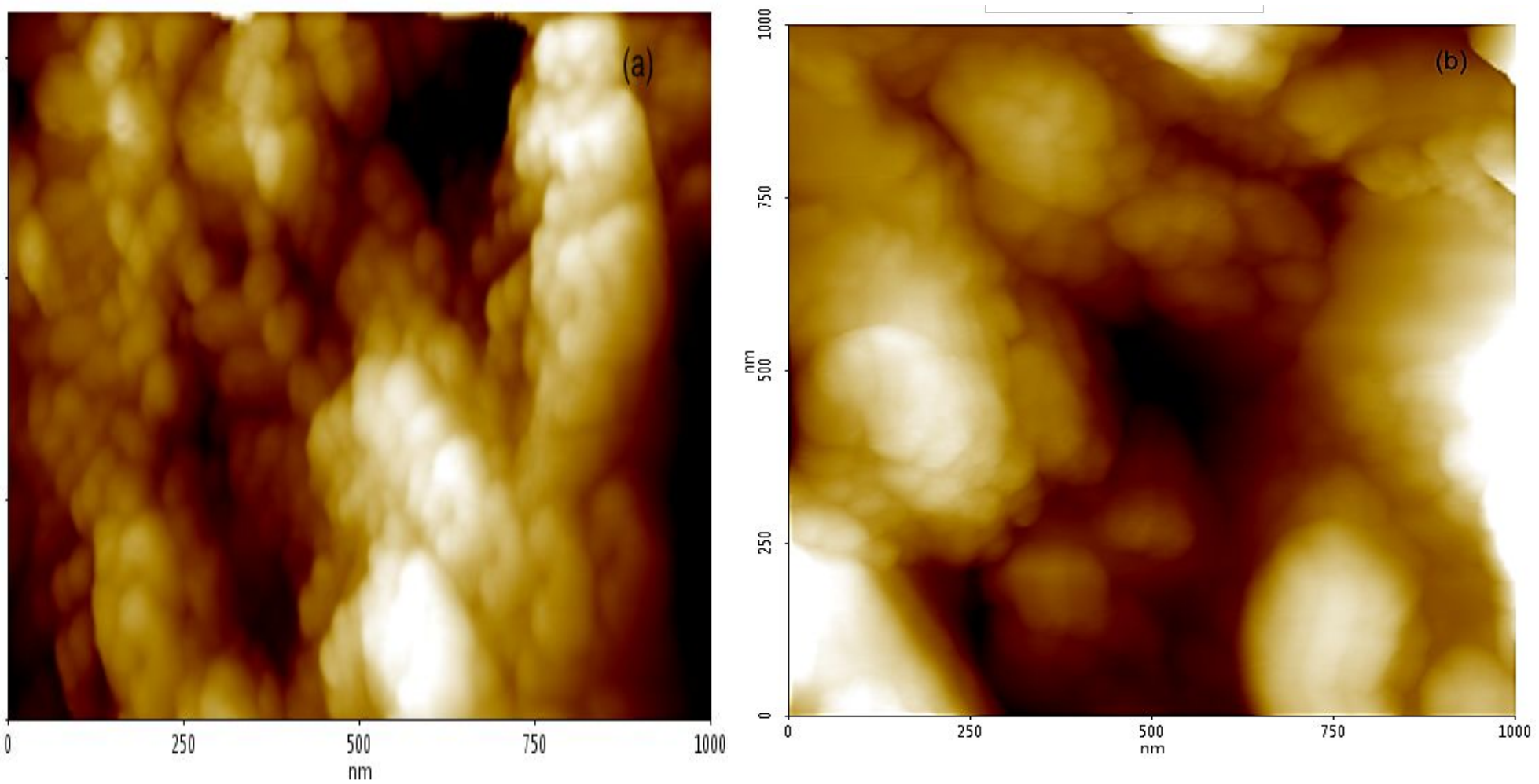

209 Figure 5. Depicts AFM image of (a) unmodified $-\mathrm{TiO}_{2}$ (b) $\mathrm{TiO}_{2}-\mathrm{C}_{4} \mathrm{H}_{5} \mathrm{KO}_{6}(1: 0.5 \mathrm{molar}$ 210 ratio)

211 
212 The surface area, pore volume and pore size were determined by BET analysis. The 213 surface area analysis of unmodified $-\mathrm{TiO}_{2}$ and $\mathrm{TiO}_{2}-0.5 \mathrm{C}_{4} \mathrm{H}_{5} \mathrm{KO}_{6}$ using $\mathrm{BET}$ is shown in 214 Table 3. The decrease in porosity of $\mathrm{TiO}_{2}$ modified with $\mathrm{C}_{4} \mathrm{H}_{5} \mathrm{KO}_{6}$ catalyst was due to the 215 insertion of potassium ions ${ }^{25}$. Even though there is a decrease in porosity and surface area, 216 but there is an increase in catalytic activity for transesterification which is depicted in Table 217 1. It may be due the action of the strength of basic sites in the catalyst ${ }^{25}$. The $\mathrm{N}_{2}$ adsorption218 desorption isotherm for $\mathrm{TiO}_{2}$ and $\mathrm{TiO}_{2}$ modified with $\mathrm{C}_{4} \mathrm{H}_{5} \mathrm{KO}_{6}$ from BET analysis is given 219 in Figure 6. The hysteretic loop isotherm indicates the presence of mesoporous materials.

$221 \quad$ Table 3.

222 The results of Brunauer-Emmett-Teller surface area analysis

\begin{tabular}{lllc}
\hline & Parameters & Unmodified & $\mathrm{TiO}_{2}-\mathrm{C}_{4} \mathrm{H}_{5} \mathrm{KO}_{6}$ \\
& & $\mathrm{TiO}_{2}$ & $(1: 0.5$ molar ratio $)$ \\
\hline Surface area & BET surface area $\left(\mathrm{m}^{2} / \mathrm{g}\right)$ & 37,58 & 16,25 \\
& BJH adsorption cumulative surface area of & 34,32 & 12,49 \\
& pores $\left(\mathrm{m}^{2} / \mathrm{g}\right)$ & & 12,75 \\
& BJH desorption cumulative surface area of & 34,41 & \\
& & &
\end{tabular}




\begin{tabular}{llll}
\hline Pore volume & Single point adsorption total pore volume of & 0,06 & 0,03
\end{tabular}

pores $\left(\mathrm{cm}^{3} / \mathrm{g}\right)$

BJH adsorption cumulative volume of pores $\quad 0,10 \quad 0,09$

$\left(\mathrm{cm}^{3} / \mathrm{g}\right)$

BJH desorption cumulative volume of pores $\quad 0,11 \quad 0,09$

$\left(\mathrm{cm}^{3} / \mathrm{g}\right)$

$\begin{array}{llll}\text { Pore size } & \text { Adsorption average pore width }\left(\mathrm{A}^{\circ}\right) & 64,31 & 72,43\end{array}$

$\mathrm{BJH}$ adsorption average pore diameter $\left(\mathrm{A}^{\circ}\right) \quad 122,41 \quad 296,76$

BJH desorption average pore diameter $\left(\mathrm{A}^{\circ}\right) \quad 129,24 \quad 291,11$

223

224

225
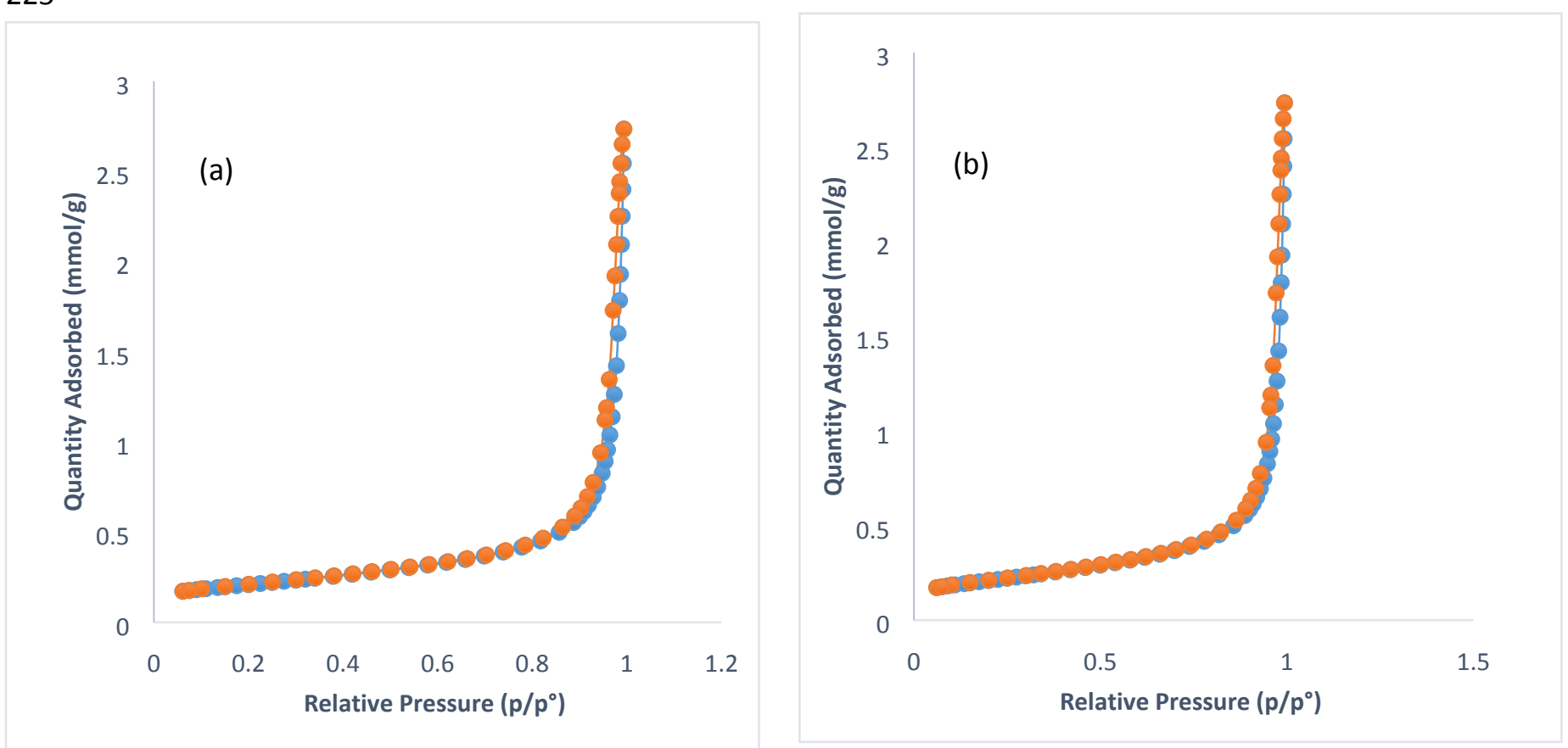
226

227

Figure 6. $\mathrm{N}_{2}$ adsorption-desorption of (a) unmodified $-\mathrm{TiO}_{2}$ (b) $\mathrm{TiO}_{2}-\mathrm{C}_{4} \mathrm{H}_{5} \mathrm{KO}_{6}$

$228(1: 0.5 \mathrm{molar}$ ratio $)$

229

230 XPS was applied to examine the surface properties and binding energies (BE) of elements

231 in unmodified $-\mathrm{TiO}_{2}$ (b) $\mathrm{TiO}_{2}-\mathrm{C}_{4} \mathrm{H}_{5} \mathrm{KO}_{6}$ (1:0.5molar ratio). The chemical environment of Ti,

$232 \mathrm{O}, \mathrm{K}$ were simulated by Gaussian curve-fitting of the Ti $2 \mathrm{p}, \mathrm{K} 2 \mathrm{p}$ and $\mathrm{O}$ 1s spectra of

233 unmodified $-\mathrm{TiO}_{2}$ and $\mathrm{TiO}_{2}-0.5 \mathrm{C}_{4} \mathrm{H}_{5} \mathrm{KO}_{6}$. Figure 7 (a) and (b) depicts XPS fitted spectra of

234 unmodified $-\mathrm{TiO}_{2}$ and $\mathrm{TiO}_{2}-0.5 \mathrm{C}_{4} \mathrm{H}_{5} \mathrm{KO}_{6}$ nanocatalyst. Both in unmodified $-\mathrm{TiO}_{2}$ and $\mathrm{TiO}_{2-}$

$2350.5 \mathrm{C}_{4} \mathrm{H}_{5} \mathrm{KO}_{6}$ depict Ti $2 p$ signals with two peaks at binding energies of 463.66 and 457.96

$236 \mathrm{eV}$ assigned to $\mathrm{Ti} 2 \mathrm{p}_{1 / 2}$ and $2 \mathrm{p}_{3 / 2}$, respectively. The BE gap between these two core level

237 orbital suggesting that chemical valance state of $\mathrm{Ti}$ in synthesized nanocatalyst is +4 . The $\mathrm{O}$

238 1s spectra of unmodified $-\mathrm{TiO}_{2}$ and $\mathrm{TiO}_{2}-0.5 \mathrm{C}_{4} \mathrm{H}_{5} \mathrm{KO}_{6}$ shows binding energy at $530.1 \mathrm{eV}$,

239 which corresponds to $\mathrm{O}^{2+}$ forming oxide with metals ${ }^{27}$. Figure $7 \mathrm{~b}$. represents $\mathrm{K} 2 \mathrm{p}$ with

240 binding energies at $292.37 \mathrm{eV}$ and $294.97 \mathrm{eV}$ which is assigned to $2 \mathrm{p}_{3 / 2}$ and $2 \mathrm{p}_{1 / 2}$ in the $\mathrm{K}-\mathrm{O}$

241 group of $\mathrm{TiO}_{2}-0.5 \mathrm{C}_{4} \mathrm{H}_{5} \mathrm{KO}_{6}{ }^{28}$.

242

243 


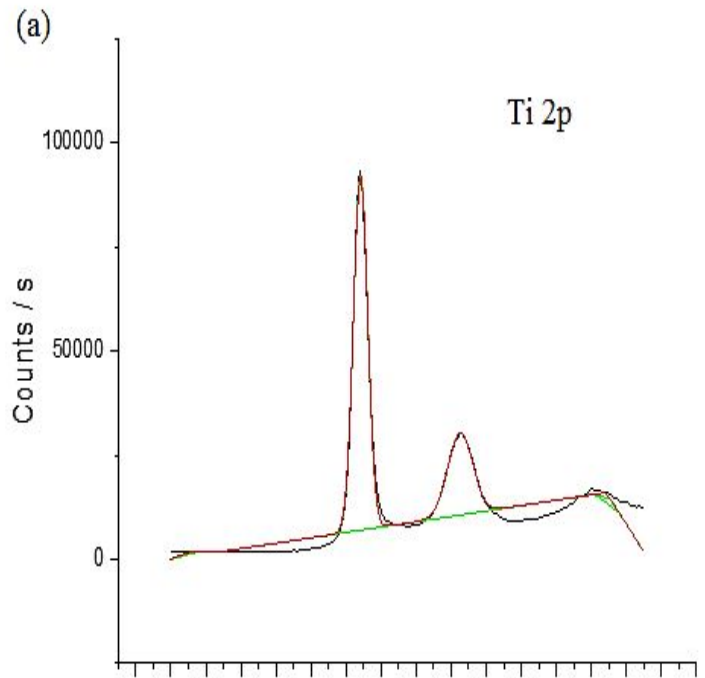

446448450452454456458460462464466468470472474476478

Binding Energy (E) (eV)

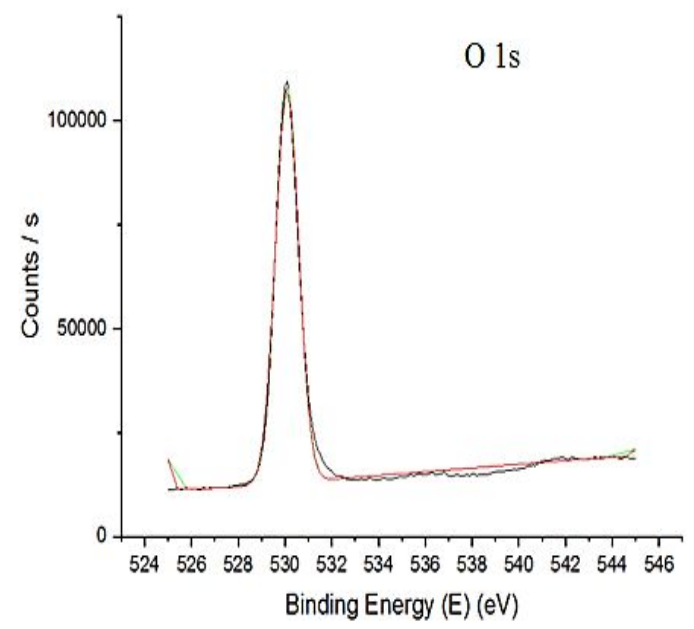

244
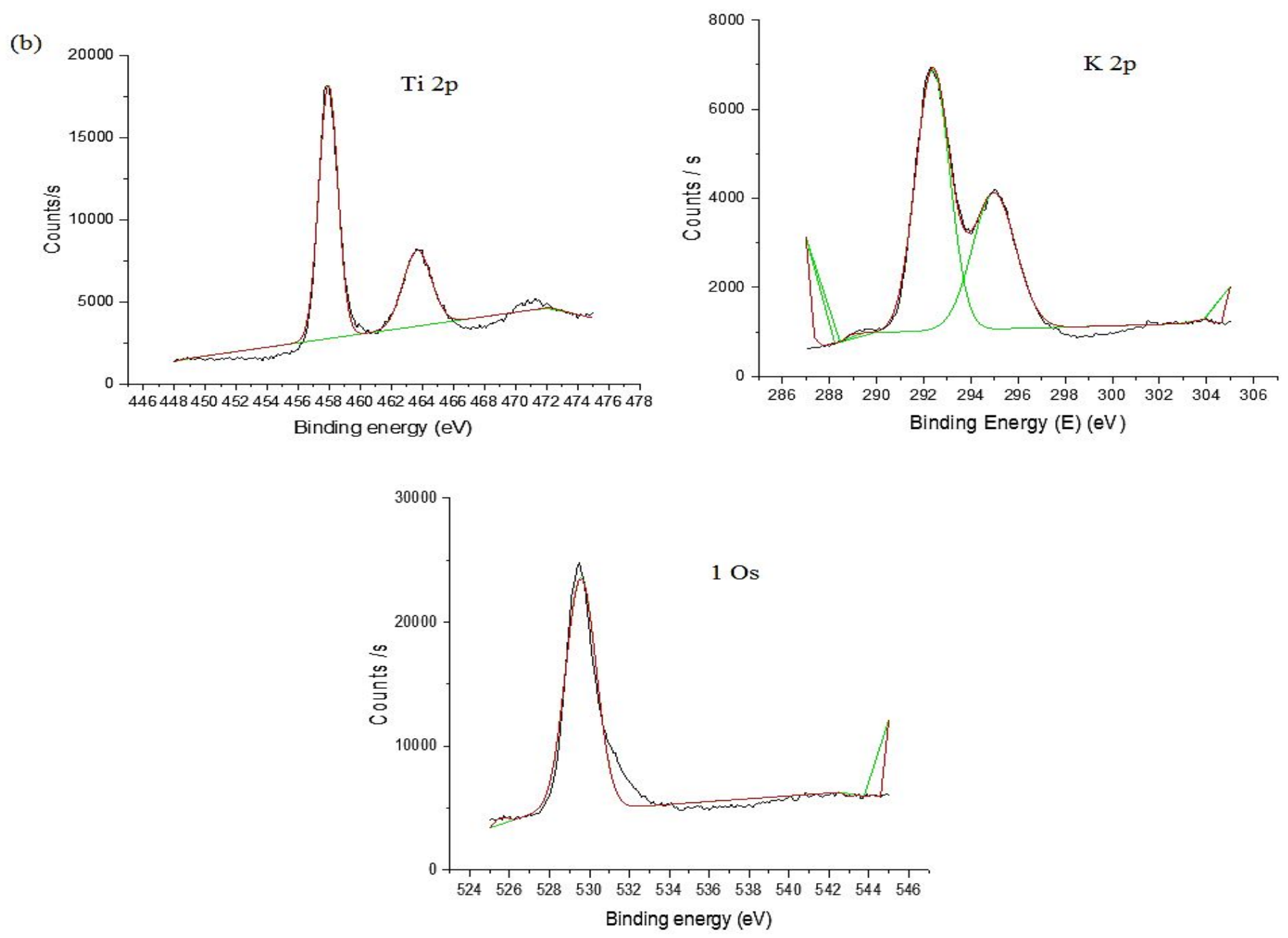
245 Figure 7. XPS spectra of (a) unmodified $-\mathrm{TiO}_{2}$ (b) $\mathrm{TiO}_{2}-\mathrm{C}_{4} \mathrm{H}_{5} \mathrm{KO}_{6}$ (1:0.5molar ratio)

246

$247 \quad$ 3.3. Characterization of biodiesel

248 The fatty acid methyl esters made from the linseed oil was characterized by GC-MS, ${ }^{1} \mathrm{H}$ 249 NMR and ${ }^{13} \mathrm{C}$ NMR. The quality of the produced biodiesel was tested using the EN 14214/ 250 ASTM D6751 method

251

252 The chemical composition of biodiesel was demonstrated with the help of GC-MS

253 chromatogram and National Institute of Standards and Technology (NIST) 2014 MS library.

254 The component of biodiesel obtained after transesterification of linseed oil with $\mathrm{TiO}_{2}-0.5$

$255 \mathrm{C}_{4} \mathrm{H}_{5} \mathrm{KO}_{6}$ was recognized with the help of a library match and represented in Table 4.

256

$257 \quad$ Table 4.

258 The composition of biodiesel attained after transesterification with $\mathrm{TiO}_{2}-0.5 \mathrm{C}_{4} \mathrm{H}_{5} \mathrm{KO}_{6}$.

\begin{tabular}{|l|l|l|l|}
\hline Peak & \multicolumn{2}{|c|}{ FAME } & \multirow{2}{*}{ Compound name \& mass spectrum } \\
\cline { 2 - 3 } & $\begin{array}{l}\text { Retention time } \\
(\mathrm{min})\end{array}$ & $\begin{array}{l}\text { Library match } \\
(\%)\end{array}$ & \\
\hline
\end{tabular}




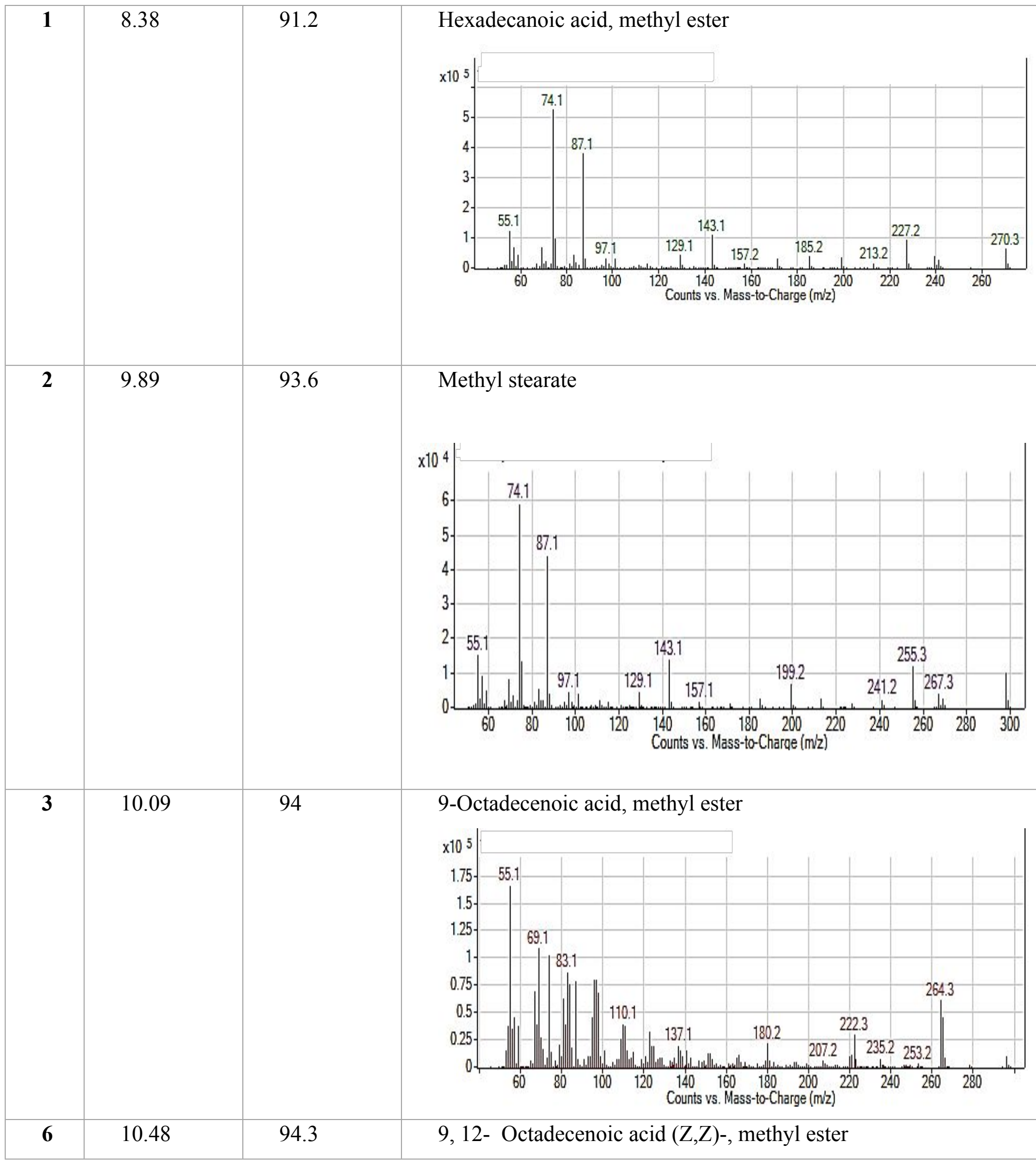




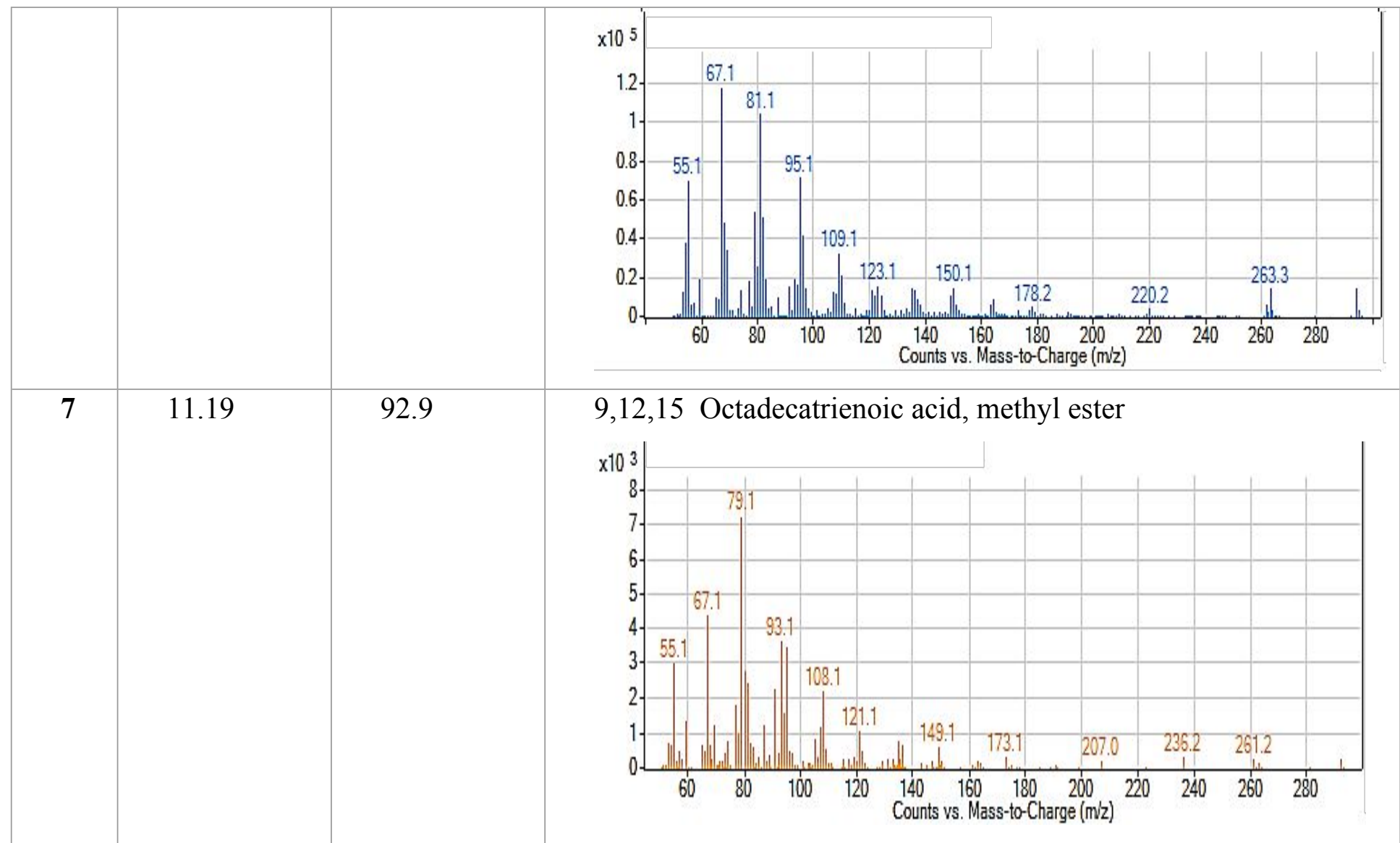

259

260

261 The analysis of fatty acid methyl esters of linseed oil was conducted by ${ }^{1} \mathrm{H}$ and ${ }^{13} \mathrm{C}$ NMR

262 spectroscopy. The biodiesel yield was calculated using equation 2, which was already

263 mentioned above. With the help of ${ }^{1} \mathrm{H}$ NMR, FAME conversion percentage of sample

264 obtained after transesterification with $\mathrm{TiO}_{2}-0.5 \mathrm{C}_{4} \mathrm{H}_{5} \mathrm{KO}_{6}$ was found to be $98.5 \%$. Figure $8 \mathrm{a}$

265 and $8 \mathrm{~b}$ illustrate the ${ }^{1} \mathrm{H}$ NMR and ${ }^{13} \mathrm{C}$ spectrum of fatty acid methyl esters sample obtained

266 with help of $\mathrm{TiO}_{2}-0.5 \mathrm{C}_{4} \mathrm{H}_{5} \mathrm{KO}_{6}$ catalyst respectively. It helps to characterize $\mathrm{FAME}$ and can

267 be used to conform the existence of methyl esters in the biodiesel. Moreover, the proposed 
268 catalyst resulted in better conversion of linseed oil to biodiesel in comparison with previously 269 reported studies using alkali as well as $\mathrm{CaO}$ as solid catalyst ${ }^{15,16}$.

270 In ${ }^{1} \mathrm{H}$ NMR the signal at $3.65 \mathrm{ppm}$ indicates methoxy group (A $\mathrm{AE}_{\mathrm{ME}}$ of FAME and signal 271 at $2.28 \mathrm{ppm}$ corresponding to methylene group $\left(\mathrm{A}_{\mathrm{CH} 2}\right)$. The presence of these signal in the 272 biodiesel sample verifies the presence of methyl ester. Apart from the signal used for the 273 quantification, there are other identifiable peaks such as signal at 0.86 to $0.87 \mathrm{ppm}$ for $\mathrm{CH}_{2^{-}}$ $274 \mathrm{CH}_{3}$ or for latter methyl group. The peaks in the range of 1.24 to 2.34 represent $\mathrm{CH}_{2}$ 275 (methylene group). The signals at 5.3 range indicate presence of $\mathrm{CH}=\mathrm{CH}$ (double bond) 276 groups or olefinic groups ${ }^{29-31}$. In ${ }^{13} \mathrm{C}$ NMR the signal at $174.25 \mathrm{ppm}$ and 51.35 indicates as 277 peak for ester carbonyl - $\mathrm{COO}$ - and $\mathrm{C}-\mathrm{O}$ respectively. The unsaturation in biodiesel sample 278 was confirmed with help of signals at $131.88 \mathrm{ppm}$ and $127.05 \mathrm{ppm}$. In addition to these 279 signals, there are other signals at $14.03 \mathrm{ppm}$ and $14.19 \mathrm{ppm}$ indicating the presence of terminal $280-\mathrm{CH}_{3}$ groups. The presence of $-\mathrm{CH}_{2}$ group was showed with help of signals in the region of $281 \quad 22-34 \mathrm{ppm}^{29}$ 


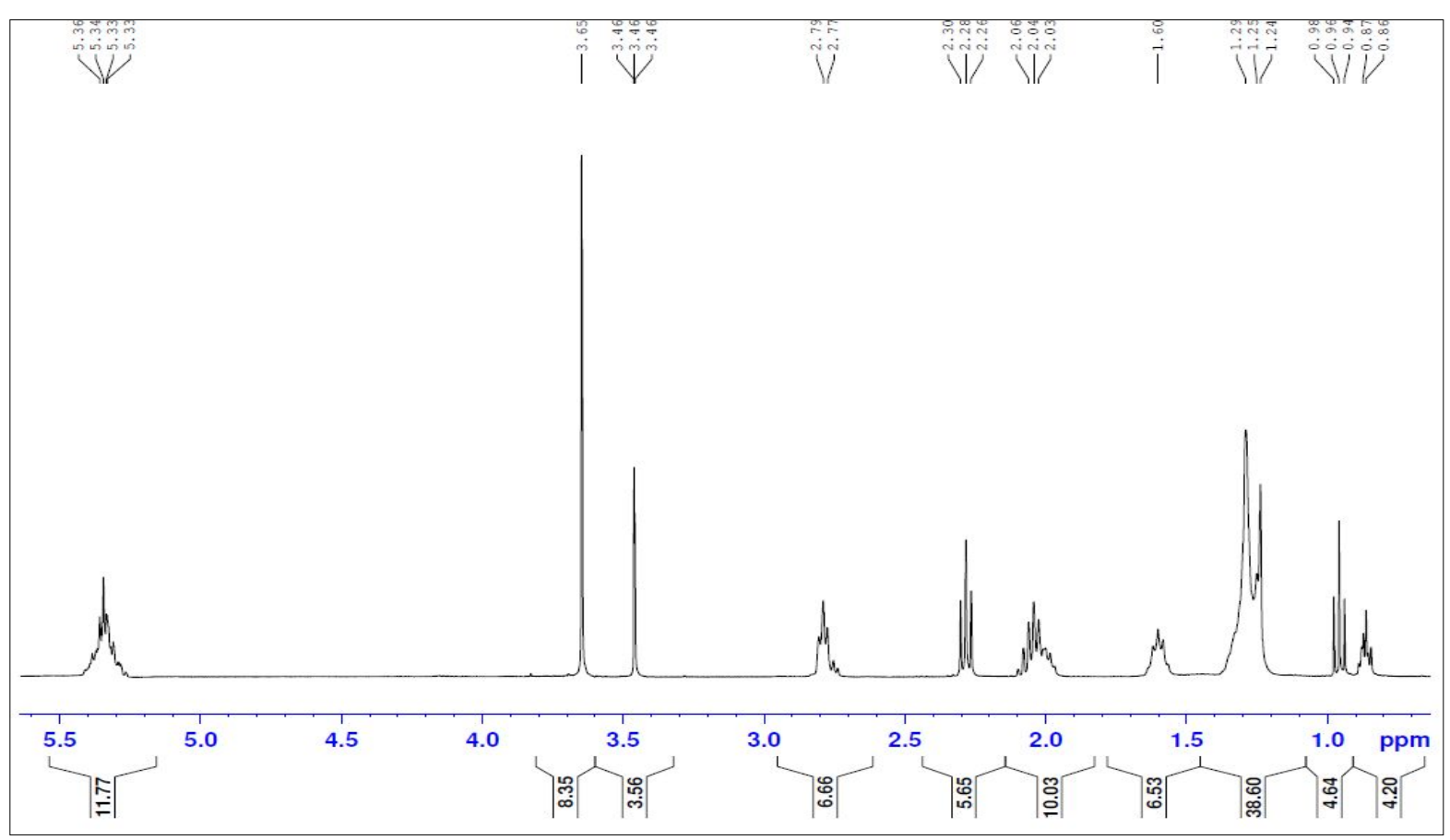

286

Figure 8 a. The ${ }^{1} \mathrm{H}$ NMR for the biodiesel sample obtained with $\mathrm{TiO}_{2}-0.5 \mathrm{C}_{4} \mathrm{H}_{5} \mathrm{KO}_{6}$ 


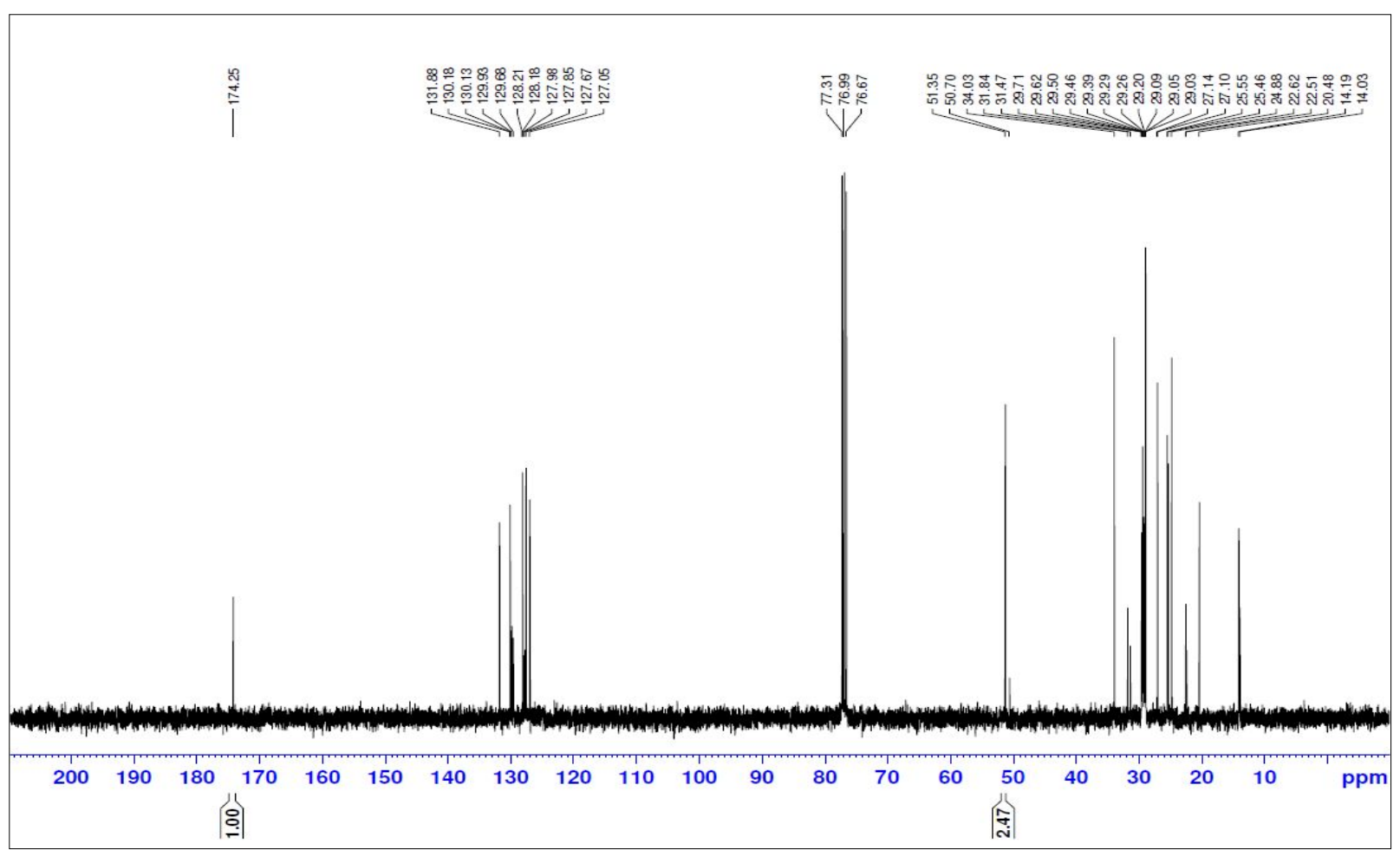

287

288 Figure 8 b. The ${ }^{13} \mathrm{C}$ NMR for the biodiesel sample obtained with $\mathrm{TiO}_{2}-0.5 \mathrm{C}_{4} \mathrm{H}_{5} \mathrm{KO}_{6}$

The yield of biodiesel depends on the reaction conditions such as methanol to oil ratio,

293 temperature, time, catalyst amount. Based on the preliminary screening of catalysts, $\mathrm{TiO}_{2^{-}}$

$294 \mathrm{C}_{4} \mathrm{H}_{5} \mathrm{KO}_{6}(1: 0.5$ molar ratio) was found to be a more efficient catalyst for the conversion of 295 linseed oil to fatty acid methyl ester. The optimum reaction conditions for higher conversion 296 of linseed oil to biodiesel using $\mathrm{TiO}_{2}-0.5 \mathrm{C}_{4} \mathrm{H}_{5} \mathrm{KO}_{6}$ was determined by a series of 297 transesterification reactions. 
298

$299 \quad$ Catalyst amount (weight \%)

300

301 The influence of catalyst concentration on transesterification was studied by performing

302 reactions at various catalyst concentration from $3 \mathrm{wt} \%$ to $12 \mathrm{wt} \%$ of the oil. The $98.5 \%$ of

303 biodiesel conversion was obtained within $3 \mathrm{~h}$ of reaction time at $60^{\circ} \mathrm{C}$ by using $6 \mathrm{wt} \%$ catalyst

304 and 1:6 oil to methanol molar ratio (Figure 9a). The conversion of oil to biodiesel depends

305 on catalyst amount, if the catalyst amount is lower than optimum concentration; there is

306 reduction in FAME conversion due to decrease in the availability of active sites and

307 hindrance to phase separation ${ }^{19,25,32}$.

308

$309 \quad 3.4 .2 \quad$ Oil to methanol molar ratio

311 Figure $9 \mathrm{~b}$ depicts that the biodiesel conversion progressively rises from when oil to

312 methanol molar ratio was increased from 1:3 to 1:6. The reaction was carried out at $6 \mathrm{wt} \%$

313 catalyst at $60^{\circ} \mathrm{C}$ for $3 \mathrm{~h}$ of reaction time. The biodiesel conversion was negatively affected by

314 increasing methanol concentration above the optimum value which was due to the increased

315 solubility of glycerol to ester phase resulting in difficulty in separation of biodiesel. It may

316 also favor the reverse reaction than the production of biodiesel ${ }^{33,34}$. 
$318 \quad 3.4 .3 \quad$ Temperature

319

320 The effect of temperature on biodiesel yield was investigated by conducting the reaction

321 at various temperatures using $6 \mathrm{wt} \%$ catalyst, 1:6 oil to methanol molar ratio for $3 \mathrm{~h}$ reaction

322 time (Figure 9c). The FAME conversion increased significantly up to $60^{\circ} \mathrm{C}$ and resulted in

323 an optimum yield of fatty acid methyl esters. After $60^{\circ} \mathrm{C}$ biodiesel conversion decreased with

324 increase in temperature, which is due to the fact that elevated temperature favors vaporization

325 of methanol $25,35,36$.

326

$327 \quad 3.4 .4 \quad$ Time

328

329 The influence of reaction time on transesterification reaction was examined by performing 330 reactions for different time intervals using $6 \mathrm{wt} \%$ catalyst, 1:6 oil to methanol molar ratio at $33160^{\circ} \mathrm{C}$ depicted in Figure $9 \mathrm{~d}$. The percentage of FAME conversion rose with the increase in 332 reaction time up to $180 \mathrm{~min}$ and reached at its maximum. After $180 \mathrm{~min}$ instead of an increase 333 in the yield of biodiesel, reduction in ester content with an increase in reaction time was 334 observed. This is due to the reversible nature of transesterification reaction. After a prolonged 335 reaction time backward reaction / reverse reaction of transesterification reaction is favored 336 which leads to the hydrolysis of esters ${ }^{35,37}$. 

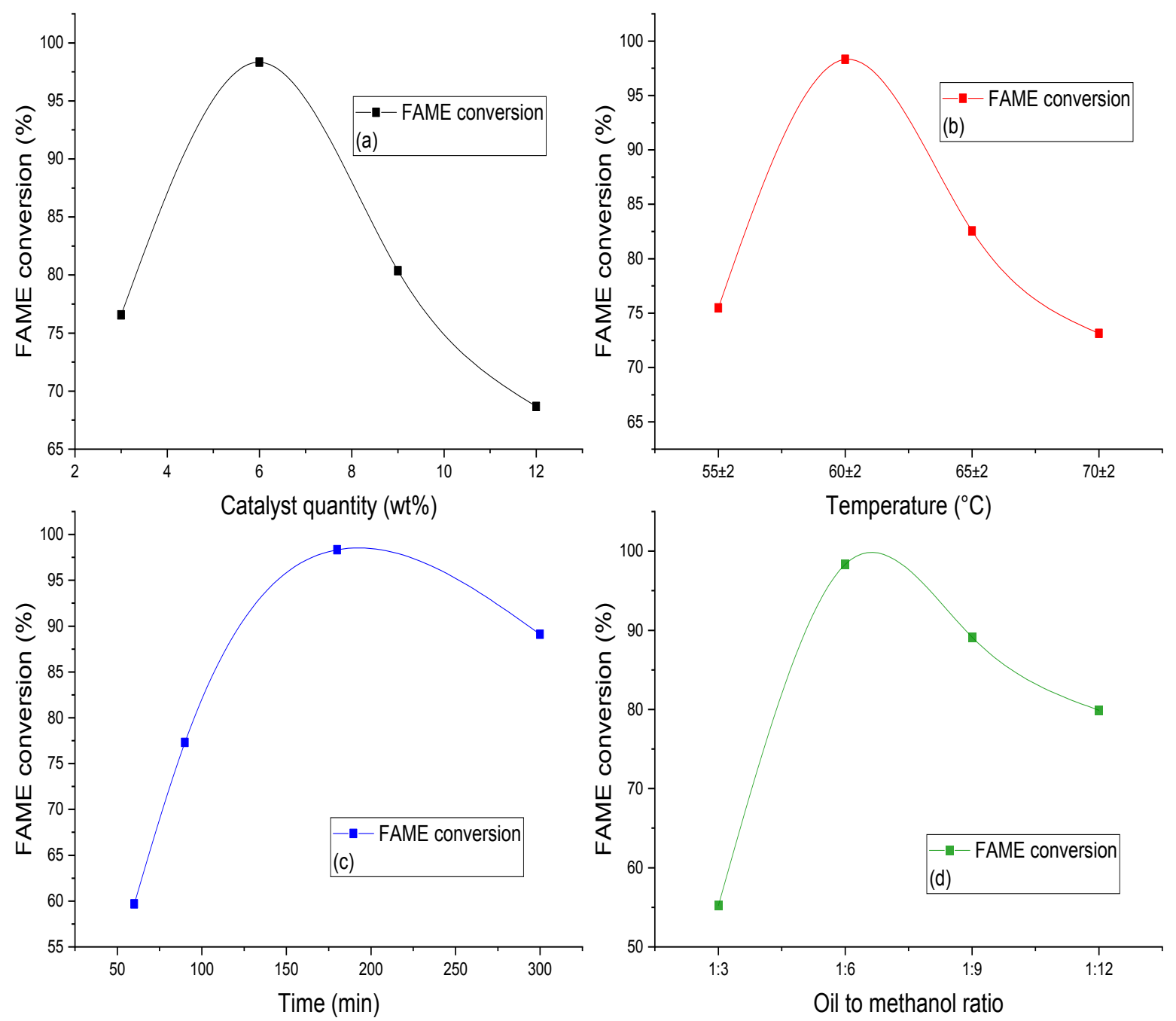

338

339

340

Figure 9. (a). Influence of catalyst amount (weight \%) on biodiesel yield (b). Influence

341 of oil to methanol molar ratio on biodiesel yield (c). Influence of reaction temperature on

342 biodiesel yield (d). Influence of reaction time on biodiesel yield. 
$344 \quad$ 3.5. Properties of synthesized biodiesel from linseed oil

345

346 The properties of linseed oil methyl esters were determined using EN 14214/ ASTM

347 D6751 method as shown in Table 5. All these parameters play an important role in biodiesel

348 quality. The acid value of linseed oil methyl ester was found to be $0.3 \mathrm{mg} \mathrm{KOH} / \mathrm{g}$ and it was

349 within the limits of EN ISO method. The increase in acid value can create issues like

350 corrosion of rubber parts of engine and filter clogging ${ }^{38}$. The other two important fuel

351 parameters which influence the fuel injection operation are density and kinematic viscosity.

352 Higher values of this can adversely affect the fuel injection process and result in the formation

353 of engine deposits ${ }^{39,40}$. The density and kinematic viscosity of linseed oil methyl esters were

$354891.52 \mathrm{~kg} / \mathrm{m}^{3}$ and $3.5709 \mathrm{~mm}^{2} / \mathrm{s}$ respectively. The other parameter is the flash point which

355 indicates the minimum temperature at which fuel starts to ignite. It is important to know flash

356 point value for fuel handling and storage ${ }^{41}$. The rest of the preferred features such as calorific

357 value, cloud point, cetane number, and pour point are also within EN ISO/ASTM limits.

358

$359 \quad$ Table 5.

360 Properties of linseed oil methyl esters $\left(\mathrm{TiO}_{2}-0.5 \mathrm{C}_{4} \mathrm{H}_{5} \mathrm{KO}_{6}\right.$ catalyst at concentration of $3616 \mathrm{wt} \%, 1: 6$ oil to methanol ratio, reaction temperature $60^{\circ} \mathrm{C}$, reaction time $3 \mathrm{~h}$ ) 


\begin{tabular}{|c|c|c|c|}
\hline Property & EN 14214 test & Limits & Methyl ester from \\
\hline
\end{tabular}

\begin{tabular}{llll}
\hline Acid value $(\mathrm{mg} \mathrm{KOH} / \mathrm{g})$ & Pr EN14104 & $0.5 \max$ & 0.3
\end{tabular}

Density at $15^{\circ} \mathrm{C}\left(\mathrm{kg} / \mathrm{m}^{3}\right) \quad$ EN ISO $12185 \quad 860-900 \quad 891.52$

Kinematic viscosity at $\quad$ EN ISO $3104 \quad 3-5$
$40^{\circ} \mathrm{C} \mathrm{mm}^{2} / \mathrm{s}$

\begin{tabular}{llll}
\hline Flash point $\left({ }^{\circ} \mathrm{C}\right)$ & EN ISO 2719 & - & $173^{\circ} \mathrm{C}$
\end{tabular}

Cetane Number $\quad$ EN ISO $5165 \quad \geq 51$

\begin{tabular}{lll}
\hline Cloud point $\left({ }^{\circ} \mathrm{C}\right)$ & $\mathrm{D} 2500$ & 4
\end{tabular}

\begin{tabular}{lll}
\hline Pour point $\left({ }^{\circ} \mathrm{C}\right)$ & ISO 3016 & 2
\end{tabular}

$\begin{array}{lll}\text { Calorific value }(\mathrm{MJ} / \mathrm{kg}) & \mathrm{D} 6751 & 40.89\end{array}$

362

$363 \quad$ 3.6. Reusability and stability of catalyst

365 The catalyst reusability concept makes transesterification process cost effective and eco366 friendlier. The catalyst deactivation is mainly due to deposition of impurities, oil content or 367 thermal deactivation. The regeneration of catalyst usually attained with help of suitable 368 solvent washing and calcination ${ }^{42}$. To analyze the reusability of $\mathrm{TiO}_{2}-0.5 \mathrm{C}_{4} \mathrm{H}_{5} \mathrm{KO}_{6}$ 369 nanocatalyst, firstly it was separated from linseed oil methyl esters and glycerol. After 
370 transesterification, the separated catalyst was washed several times with heptane to remove

371 impurities. The washed catalyst was dried at $90^{\circ} \mathrm{C}$ and calcined at $500^{\circ} \mathrm{C}$ for $3 \mathrm{~h}$ to reactivate

372 the catalyst. The catalytic reusability of $\mathrm{TiO}_{2}-0.5 \mathrm{C}_{4} \mathrm{H}_{5} \mathrm{KO}_{6}$ over linseed oil using $6 \mathrm{wt} \%$

373 catalyst, 1:6 oil to methanol molar ratio within $180 \mathrm{~min}$ of reaction time at $60^{\circ} \mathrm{C}$ represented

374 in Figure 10. Linseed oil to FAME conversion was decreased from $98.5 \%$ to $93.1 \%$,

375 respectively, in five cycles.

376 Stability of nanocatalyst after different cycles were evaluated by determining the leached

377 metal ion concentration depicted in Figure 10. Inductively coupled plasma (ICP, Agilent

378 5110) was used to measure metal concentration. It was detected that from cycle 1 to cycle 5,

379 the Li concentrations in solution are less than $0.043 \mathrm{mg} / \mathrm{L}$. Moreover, Ti concentration in 380 solution was null up to three cycles after that there was a slight leaching of Ti ions to solution 381 which is less than $0.0004 \mathrm{mg} / \mathrm{L}$
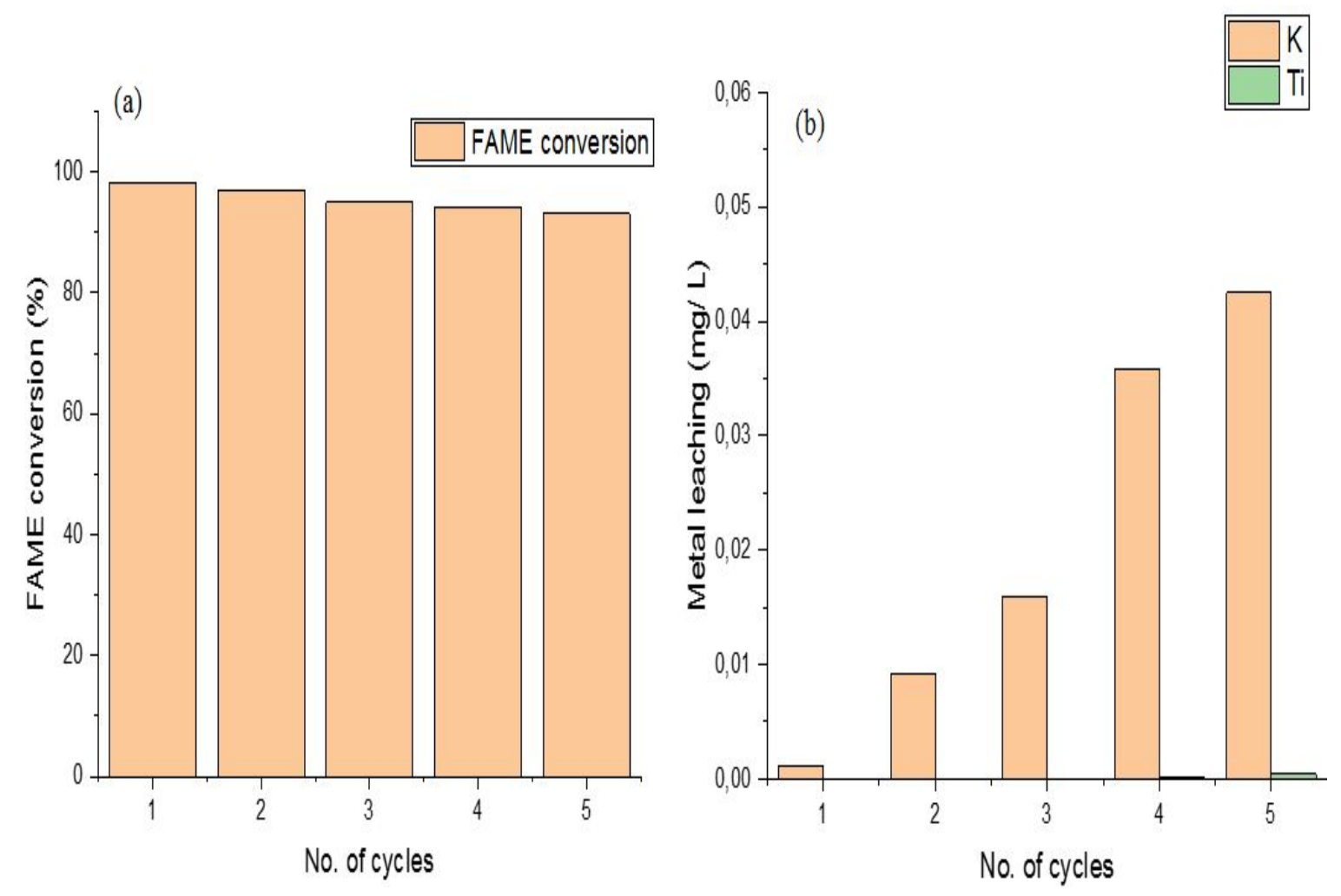
383

384

385

386

387

388

389

390

391

392

393

394

395

396

397

398

399

400

401

402

403

Figure 10. Reusability analysis of $\mathrm{TiO}_{2}-0.5 \mathrm{C}_{4} \mathrm{H}_{5} \mathrm{KO}_{6}$ catalyst up to five transesterification reactions

\section{Conclusion}

The biodiesel was successfully synthesized from linseed oil with help of $\mathrm{TiO}_{2}-0.5$ $\mathrm{C}_{4} \mathrm{H}_{5} \mathrm{KO}_{6}$. The modification of $\mathrm{TiO}_{2}$ with $\mathrm{C}_{4} \mathrm{H}_{5} \mathrm{KO}_{6}$ enhanced the properties of nanocatalyst due to impregnation of potassium and showed better conversion in comparison to unmodified $\mathrm{TiO}_{2}$. FTIR, XRD, SEM, TEM, AFM confirmed the integration of potassium ions to $\mathrm{TiO}_{2}$ nanostructure. The best activity was obtained at an optimum loading of $\mathrm{C}_{4} \mathrm{H}_{5} \mathrm{KO}_{6}$ to $\mathrm{TiO}_{2}$ in 0.5:1 molar ratio. The nanocatalyst showed $98.5 \%$ fatty acid methyl ester content using $6 \mathrm{wt}$ $\%$ catalyst amount, 1:6 methanol ratio at $60^{\circ} \mathrm{C}$ within a reaction time of $3 \mathrm{~h}$. The properties of biodiesel such as acid value, density, kinematic viscosity and flash point were within the EN 14214 limits. Thus, FAME obtained was of good quality. All these results supports the efficient performance of $\mathrm{TiO}_{2}-0.5 \mathrm{C}_{4} \mathrm{H}_{5} \mathrm{KO}_{6}$ as a catalyst for the biodiesel production from linseed oil as a feedstock. The reusability of the catalyst also showed a promising result, which makes it economically feasible. 
$404 \quad$ References

405 [1] Demirbas A. Importance of biodiesel as transportation fuel. Energy Policy 2007, 35, $406 \quad$ 4661-4670.

407 [2] Singh SP, Singh D. Biodiesel production through the use of different sources and 408 characterization of oils and their esters as the substitute of diesel: A review. Renew 409 Sustain Energy Rev 2010, 14, 200-216. doi:10.1016/j.rser.2009.07.017.

410 [3] Li Y, Qiu F, Yang D, Li X, Sun P. Preparation, characterization and application of 411 heterogeneous solid base catalyst for biodiesel production from soybean oil. Biomass $412 \quad$ and Bioenergy 2011,35, 2787-2795.

413 [4] Rashtizadeh E, Farzaneh F. Transesterification of soybean oil catalyzed by Sr-Ti 414 mixed oxides nanocomposite. J Taiwan Inst Chem Eng 2013, 44, 917-923.

415 [5] Hu S, Guan Y, Wang Y, Han H. Nano-magnetic catalyst $\mathrm{KF} / \mathrm{CaO}-\mathrm{Fe}_{3} \mathrm{O}_{4}$ for biodiesel 416 production. Appl Energy 2011, 88, 2685-2690.

417 [6] Liu H, Su L, Shao Y, Zou L. Biodiesel production catalyzed by cinder supported $418 \quad \mathrm{CaO} / \mathrm{KF}$ particle catalyst. Fuel 2012, 97, 651-657.

419 [7] Madhuvilakku R, Piraman S. Biodiesel synthesis by $\mathrm{TiO}_{2}-\mathrm{ZnO}$ mixed oxide 420 nanocatalyst catalyzed palm oil transesterification process. Bioresour Technol 2013, $421 \quad 150,55-59$.

422 [8] Qiu F, Li Y, Yang D, Li X, Sun P. Heterogeneous solid base nanocatalyst: Preparation, 423 characterization and application in biodiesel production. Bioresour Technol 2011, 102, 
425

426

427

428

429

430

431

432

433

434

435

436

437

438

439

440

441

442

443

444

[9] Kaur M, Ali A. Lithium ion impregnated calcium oxide as nano catalyst for the biodiesel production from karanja and jatropha oils. Renew Energy 2011, 36, 28662871.

[10] Baskar G, Selvakumari IAE, Aiswarya R. Biodiesel production from castor oil using heterogeneous Ni doped ZnO nanocatalyst. Bioresour Technol 2018, 250, 793-798.

[11] Ding H, Ye W, Wang Y, Wang X, Li L, Liu D, et al. Process intensification of transesterification for biodiesel production from palm oil : Microwave irradiation on transesterification reaction catalyzed by acidic imidazolium ionic liquids Energy 2018, $144,957-967$.

[12] Teo SH, Islam A, Taufiq-Yap YH. Algae derived biodiesel using nanocatalytic transesterification process. Chemical engineering research and design 2016, 111, 362-370.

[13] Ambat I, Srivastava V, Sillanpää M. Recent advancement in biodiesel production methodologies using various feedstock : A review . Renewable and sustainable energy reviews 2018, 90, 356-369.

[14] Aransiola EF, Ojumu T V., Oyekola OO, Madzimbamuto TF, Ikhu-Omoregbe DIO. A review of current technology for biodiesel production: State of the art. Biomass and Bioenergy 2014, 61, 276-297.

[15] Kumar R, Tiwari P, Garg S. Alkali transesterification of linseed oil for biodiesel production. Fuel 2013, 104, 553-560. 
445 [16] Gargari MH, Sadrameli SM. Investigating continuous biodiesel production from 446 linseed oil in the presence of a Co-solvent and a heterogeneous based catalyst in a packed bed reactor. Energy 2018, 148, 888-895.

448

[17] Akia M, Yazdani F, Motaee E, Han D, Arandiyan H. A review on conversion of 449 biomass to biofuel by nanocatalysts. Biofuel Res $J$ 2014,1, 16-25.

450

451

[18] Hashmi S, Gohar S, Mahmood T, Nawaz U, Farooqi H. Biodiesel Production by using CaO-Al ${ }_{2} \mathrm{O}_{3}$ Nano Catalyst. Int J Eng Res Sci 2016, 2, 2395-6992.

[19] Takase M, Chen Y, Liu H, Zhao T, Yang L, Wu X. Biodiesel production from non453 edible Silybum marianum oil using heterogeneous solid base catalyst under ultrasonication. Ultrason Sonochem 2014, 21, 1752-62.

[20] Fadhil AB, Al-tikrity ETB, Khalaf AM. Transesterification of non-edible oils over 456 potassium acetate impregnated $\mathrm{CaO}$ solid base catalyst. Fuel 2018, 234, 81-93.

[21] Fadhil AB, Aziz AM, Altamer MH. Optimization of methyl esters production from non-edible oils using activated carbon supported potassium hydroxide as a solid base catalyst. Arab J Basic Appl Sci 2018, 25, 56-65.

[22] Buasri A, Worawanitchaphong P, Trongyong S. Utilization of Scallop Waste Shell for Biodiesel Production from Palm Oil - Optimization Using Taguchi Method. Procedia - Soc Behav Sci 2014, 8, 216-221.

[23] Bagheri S, Julkapli NM, Bee S, Hamid A. Titanium Dioxide as a Catalyst Support in Heterogeneous Catalysis . The scientific world journal 2014, 465 doi.org/10.1155/2014/727496. 
466 [24] Thitsartarn W, Kawi S. An active and stable $\mathrm{CaO}-\mathrm{CeO} 2$ catalyst for 467 transesterification of oil to biodiesel. Green Chemistry 2011, 13, 3423- 3430.

468

[25] Singh V, Bux F, Sharma YC. A low cost one pot synthesis of biodiesel from waste 469 470 frying oil (WFO) using a novel material, $\beta$-potassium dizirconate $\left(\beta-\mathrm{K}_{2} \mathrm{Zr}_{2} \mathrm{O}_{5}\right)$. Appl Energy 2016, 172, 23-33.

[26] Yan S, Kim M, Salley SO, Ng KYS. Oil transesterification over calcium oxides modified with lanthanum. Applied Catalysis A : General 2009, 360, 163-170.

[27] Wang X, Xiang Q, Liu B, Wang L, Luo T, Chen D, et al. TiO 2 modified FeS Nanostructures with Enhanced Electrochemical Performance for Lithium-Ion Batteries . Scientific reports: 2013, 3, 1-8.

[28] Hu S, Li F, Fan Z, Wang F, Zhao Y, Lv Z. Band gap-tunable potassium doped graphitic carbon nitride with enhanced mineralization ability. Dalton Trans. 2015,44, 1084-1092.

[29] Tariq M, Ali S, Ahmad F, Ahmad M, Zafar M, Khalid N, et al. Identification, FT-IR, NMR (1H and 13C) and GC/MS studies of fatty acid methyl esters in biodiesel from rocket seed oil. Fuel Process Technol 2011, 92, 336-341.

[30] Thangaraj B, Piraman S. Heteropoly acid coated $\mathrm{ZnO}$ nanocatalyst for Madhuca indica biodiesel synthesis. Biofuels 2016, 7(1), 13-20.

[31] Mello VM, Oliveira FCC, Fraga WG, Claudia J, Suarez PAZ. Determination of the content of fatty acid methyl esters ( FAME ) in biodiesel samples obtained by esterification using 1 H-NMR spectroscopy. MagnResonChem 2008, 46, 1051-1054. 
487 [32] Encinar JM, Pardal A, Sánchez N. An improvement to the transesterification process 488 by the use of co-solvents to produce biodiesel. Fuel 2016, 166, 51-58.

489

490

491

492

493

494

495

496

497

498

499

500

501

502

503

504

505

506

507
[33] Banihani FF. Transesterification and Production of Biodiesel from Waste Cooking Oil : Effect of Operation Variables on Fuel Properties. American Journal of Chemical Engineering 2017, 4, 154-160.

[34] Kafui G, Sunnu A, Parbey J. Effect of biodiesel production parameters on viscosity and yield of methyl esters : Jatropha curcas, Elaeis guineensis and Cocos nucifera. Alexandria Eng J 2015, 54,1285-1290.

[35] Eevera T, Rajendran K, Saradha S. Biodiesel production process optimization and characterization to assess the suitability of the product for varied environmental conditions. Renew Energy 2009, 34, 762-765.

[36] Abbah EC, Nwandikom GI, Egwuonwu CC, Nwakuba NR. Effect of Reaction Temperature on the Yield of Biodiesel From Neem Seed Oil. Am J Energy Sci 2016, 3, 16-20.

[37] Ofoefule AU, Ibeto CN, Ugwu LC, Eze DC. Determination of Optimum Reaction Temperature and Reaction Time for Biodiesel Yield from Coconut ( Cocos nucifera ) Oil. International Research Journal of Pure \& Applied Chemistry 2014, 4(1), 108-117

[38] Chhetri AB, Watts KC, Islam MR. Waste Cooking Oil as an Alternate Feedstock for Biodiesel Production. Energies 2008,1, 3-18.

[39] Demirbas A. Biodiesel: A realistic fuel alternative for diesel engines. Biodiesel A Realis Fuel Altern Diesel Engines 2008:1-208. doi:10.1007/978-1-84628-995-8. 
508 [40] Knothe G, Steidley KR. Kinematic viscosity of biodiesel fuel components and related 509 compounds. Influence of compound structure and comparison to petrodiesel fuel $510 \quad$ components. Fuel 2005, 84, 1059-1065.

511 [41] Aleme HG, Barbeira PJS. Determination of flash point and cetane index in diesel using 512 distillation curves and multivariate calibration. Fuel 2012, 102, 129-134.

513 [42] Prescott W V., Schwartz AI. Nanorods and Nanomaterials Research Progress 2008, $514 \quad$ Nova science publishers, ISBN 978-1-60456-122-7 .

515

516

517

518

519 